\begin{tabular}{|c|c|c|c|}
\hline KULTURA & \multicolumn{3}{|c|}{$\begin{array}{l}\text { POLSKA AKADEMIA NAUK } \\
\text { KOMITET SOCJOLOGII } \\
\text { INSTYTUT STUDIÓW POLITYCZNYCH }\end{array}$} \\
\hline & 2010, nr 3 & „POZNAĆ, CO MYŚL & NIEJSI" \\
\hline
\end{tabular}

STANISEAWA GOLINOWSKA

Uniwersytet Jagielloński — Collegium Medicum

Instytut Pracy i Spraw Socjalnych

\title{
PODATNOŚĆ MŁODZIEŻY NA UBÓSTWO I WYKLUCZENIE SPOŁECZNE
}

\section{WPROWADZENIE}

Młodzież ${ }^{1}$ należy do tych grup ludności, które uznaje się za bardziej niż przeciętnie wrażliwe czy podatne na oddziaływanie niekorzystnych sytuacji oraz ulegające negatywnym tendencjom rozwojowym. Jest to zależność uniwersalna, ale jednocześnie specyficzna dla krajów regionu Europy Środkowej i Wschodniej, które w latach dziewięćdziesiątych podjęły trud transformacji swych systemów gospodarczych: od systemu gospodarki centralnie planowanej do systemu gospodarki rynkowej. Transformacja zwiększyła zagrożenia rozwoju młodych ludzi ze względu na radykalne zmiany wartości społecznych (wzrost znaczenia wartości indywidualistycznych i materialistycznych) oraz pewną destabilizację wszystkich instytucji, które stanowią tradycyjne oparcie dla osób dorastających, a głównie rodziny i szkoły. Stało się to nawet podstawą tezy o porzuconej generacji, sformułowanej przez badaczy amerykańskich (zob. Szafraniec 2009; Tarkowska 2009). Przyjrzyjmy się, na szerokim tle porównawczym, jak bardzo polska młodzież jest podatna na zagrożenia rozwojowe w podstawowych sferach życia.

Przedstawiona tu zostanie analiza zagrożeń rozwoju młodzieży w szerokim kontekście podatności na ubóstwo i wykluczenie społeczne. W analizie tej wy-

\section{Adres do korespondencji: stanislawa.golinowska@uj.edu.pl}

${ }^{1}$ Pojęciem młodzieży obejmuje się populację osób, które weszły w wiek dojrzewania po ukończeniu szkoły podstawowej aż do wieku ukończenia nauki na poziomie wyższym. W statystykach międzynarodowych, wzorem propozycji ONZ, za wiek młodzieżowy przyjmuje się lata 15-24, z wyróżnieniem dwóch podokresów: 15-18 i 19-24. W niektórych raportach, opisujących sytuację młodzieży w krajach rozwijających się, okres młodzieżowy wyznacza się wcześniej: od dwunastego (na przykład w raportach Banku Światowego), a nawet od dziesiątego roku życia (w niektórych pracach UNICEF) (za: UNFPA 2008). 
korzystano podejście wielowymiarowe, bazujące na psychologicznej koncepcji zrównoważonego rozwoju dziecka w podstawowych jego wymiarach (Białek 2009). Podstawę informacyjną stanowią międzynarodowe bazy danych (ONZ, WHO, OECD, UNICEF, Eurostat i Komisja Europejska) o społecznym i zdrowotnym rozwoju populacji oraz wyniki porównawczych randomizowanych badań dotyczących młodzieży. W opisie wykorzystano standardowe wskaźniki, konstruowane na potrzeby statystyki, raportów i programów służących przede wszystkim diagnozie ogólnej sytuacji społecznej i w poszczególnych dziedzinach oraz $\mathrm{w}$ odniesieniu do wybranych grup populacji. Nawiązano tym samym do dorobku „ruchu wskaźników społecznych”, na bazie którego powstało wiele raportów stanowiących podstawę wiedzy o przebiegu procesów społecznych (social reporting). Dzięki rozwojowi zbiorów informacji harmonizowanych z odpowiednimi wskaźnikami znacznie większe stały się możliwości budowania wiedzy na temat tendencji rozwojowych w różnych sferach i grupach, $\mathrm{w}$ tym także $\mathrm{w}$ populacji młodzieży. W opracowaniu zastosowano wiele różnych wskaźników ${ }^{2}$, które uwzględniają wielowymiarowe zagrożenia rozwoju młodych ludzi.

Podatność młodzieży na ubóstwo i wykluczenie społeczne wynika zarówno z przedłużenia niekorzystnych uwarunkowań z okresu dzieciństwa, jak i uwarunkowań nowych, tych, które pojawiają się w późniejszym okresie życia. Te pierwsze dotyczą przede wszystkim sfery zdrowia. Gdy występują nadal w okresie dorastania, to kapitał ludzki wówczas kształtowany traci swój potencjał rozwojowy. Zagrożeniem dobrego zdrowia są: złe odżywianie się, ograniczenia aktywności fizycznej, podatność na wypadki i urazy oraz choroby zakaźne (w tym przenoszone drogą płciowa), a także ryzykowne zachowania, związane $z$ paleniem papierosów, nadużywaniem alkoholu oraz sięganiem po narkotyki.

Do nowych uwarunkowań rozwoju kapitału ludzkiego należą możliwości dalszej edukacji, pozwalającej młodym ludziom na zdobywanie kwalifikacji i dobre wejście na rynek pracy. Brak możliwości dalszej edukacji to zagrożenie najpoważniejsze z perspektywy szans dobrego zabezpieczenia materialnego w dorosłym życiu.

Ze względu na specyfikę młodego wieku, szczególnie dużą wówczas ciekawość świata i doznań, młodzież jest bardziej podatna na destrukcyjne wpływy środowiska; zagrożenie powstawaniem uzależnień, przestępczością, przedwczesnym i ryzykownym życiem seksualnym.

\footnotetext{
2 Na przykład proponowane przez UNFPA (2008) do wykorzystania przy kształtowaniu polityki krajów wobec młodzieży czy przez ONZ w ramach Milenijnych Celów Rozwoju, w których wskaźniki obejmujące problemy ubóstwa młodzieży są ujęte w specjalnie rozwinięty aneks. Także Komisja Europejska w raporcie na temat młodzieży (European Commission 2009a) zaproponowała swoje wskaźniki monitorowania rozwoju młodych ludzi.
} 
Młodzi ludzie stają się też grupą wykorzystywaną: do nadmiernej pracy, do zajęć domowych i opiekuńczych ograniczających szanse edukacyjne, emocjonalnie uzależnianą i seksualnie molestowaną.

\section{ZAGROŻENIA ZDROWIA MŁODZIEŻY}

W życiu człowieka okres, gdy jest nastolatkiem, ma szczególne znaczenie dla kształtowaniu jego zdrowia psychicznego i somatycznego. Przechodzenie od fazy bycia dzieckiem do fazy bycia dorosłym trwa krótko, a zmiany dokonujące się wówczas są ogromne. Zmienia się ciało, pojawia się zdolność do funkcji prokreacyjnych i na tym tle budzą się potrzeby seksualne oraz wzrastają potrzeby emocjonalne. Zwiększają się obowiązki związane z edukacją. Pojawiają się silne potrzeby poznawcze oraz te związane $z$ określaniem własnej tożsamości. To powoduje, że młodzież $\mathrm{w}$ tym okresie jest szczególnie podatna na ryzykowne dla zdrowia zachowania, próbuje wchodzić w nowe sfery życia, nie zawsze bezpieczne dla jej korzystnego rozwoju w przyszłości.

Miarodajne opisanie głównych obszarów zagrożeń zdrowia młodzieży wymaga dostępu do odpowiednich informacji oraz zdefiniowanych miar i wskaźników (zob. zestawienie 1). Najpewniejsze dane w dziedzinie ochrony zdrowia pochodzą ze statystyki zgonów ${ }^{3}$ oraz korzystania $z$ usług zdrowotnych. Ponadto istotnym źródłem danych o zachowaniach zdrowotnych młodzieży w wieku dojrzewania są międzynarodowe badania przeglądowe „Zachowania zdrowotne dzieci w wieku szkolnym" (Health Behaviour in School-aged Children — dalej jako HBSC) ${ }^{4}$.

Obraz zagrożeń zdrowia wśród młodzieży w Polsce nie obiega istotnie od przeciętnego obrazu dla krajów europejskich, ale znacznie różni się od sytuacji krajów europejskiej czołówki, do której należą kraje skandynawskie. Główne zagrożenia wynikają z tzw. przyczyn zewnętrznych i mają charakter zagrożeń środowiskowych. Wskaźnik umieralności młodzieży w wieku 15-19 lat z powodów zewnętrznych (na 100 tys. osób w tym wieku) jest wyższy lub taki sam jak wskaźnik umieralności ogólnej w niektórych krajach Europy Zachodniej. Polska młodzież nierzadko ulega wypadkom i urazom przyczyniającym się do śmierci lub kalectwa. Jest to najczęstsza przyczyna zgonów. Wskaźnik umieralności młodzieży z powodów zewnętrznych jest szczególnie wysoki w krajach byłego Związku Radzieckiego, na czele z Rosją i krajami bałtyckimi (zob. tabela 1). Dominują tu wypadki komunikacyjne, wypadki w szkole (często na zajęciach sportowych) oraz bójki.

\footnotetext{
3 Statystyka ta też ma pewne nierzetelności oraz braki, głównie dotyczące charakterystyki społecznej osób zmarłych.

4 Badania te w odniesieniu do Polski prowadzi Instytut Matki i Dziecka (Mazur, Woynarowska 2004).
} 
Zagrożenia zdrowia młodzieży

\begin{tabular}{|c|c|}
\hline Obszary zagrożeń & Miary, wskaźniki i tendencje \\
\hline $\begin{array}{l}\text { Ryzykowne zachowania rwiązane } \\
\text { z mobilnością i spędzaniem czasu wol- } \\
\text { nego }\end{array}$ & $\begin{array}{l}\text { Wskaźniki umieralności z powodu tzw. zewnętrznych } \\
\text { przyczyn zgonów, w tym wypadków i urazów; najbar- } \\
\text { dziej ważąca przyczyna zgonów młodzieży w Polsce } \\
\text { i w Europie. }\end{array}$ \\
\hline Palenie papierosów & $\begin{array}{l}\text { Na podstawie deklaracji młodzieży w badaniach randomi- } \\
\text { zowanych; tendencja wzrostowa, w tym upowszechnianie } \\
\text { się palenia towarzyskiego, także wśród dziewcząt. }\end{array}$ \\
\hline Inicjacja alkoholowa & $\begin{array}{l}\text { Wiek, w którym dziecko po raz pierwszy nadużyło alko- } \\
\text { holu; wczesny wiek częściej wśród dziewcząt, następnie } \\
\text { picie staje się bardziej powszechne wśród chłopców. }\end{array}$ \\
\hline Zażywanie narkotyków & $\begin{array}{l}\text { Na podstawie deklaracji młodzieży w badaniach rando- } \\
\text { mizowanych; w Polsce wskaźniki wzrostu zażywania ma- } \\
\text { rihuany wśród młodzieży są wyższe niż przeciętnie dla } \\
\text { krajów UE. }\end{array}$ \\
\hline Depresje i inne zaburzenia psychiczne & $\begin{array}{l}\text { Chorujący na zaburzenia mentalne i podejmujący próby } \\
\text { samobójcze oraz popełniający samobójstwa (wskaźnik sa- } \\
\text { mobójstw chłopców na } 100 \text { tys. mieszkańców); tendencja } \\
\text { wzrostowa, występująca z podobnym nasileniem w kra- } \\
\text { jach europejskich, z pewnymi wyjątkami: kraje bałtyckie } \\
\text { i Finlandia. }\end{array}$ \\
\hline Wadliwe odżywianie & $\begin{array}{l}\text { Niedożywienie i otyłość (udział osób nie osiągających } \\
\text { oraz istotnie przekraczających BMI w odpowiednich gru- } \\
\text { pach wieku); w Polsce oba zjawiska występują w podobnej } \\
\text { skali. }\end{array}$ \\
\hline Niedostateczna aktywność fizyczna & $\begin{array}{l}\text { Wskaźnik czasu poświęcanego aktywności fizycznej } \\
\text { w ciągu dnia lub tygodnia. Chłopcy są dwukrotnie bar- } \\
\text { dziej aktywni niż dziewczęta. Konkurencją dla wzrostu } \\
\text { aktywności fizycznej jest oglądanie telewizji i internet. }\end{array}$ \\
\hline $\begin{array}{l}\text { Wczesna i niezabezpieczona inicjacja } \\
\text { seksualna }\end{array}$ & $\begin{array}{l}\text { Na podstawie deklaracji młodzieży w badaniach randomi- } \\
\text { zowanych; wzrost w Polsce tendencji do wstrzemięźliwo- } \\
\text { ści płciowej. }\end{array}$ \\
\hline Zachowania agresywne & $\begin{array}{l}\text { Udział w bójkach, częściej chłopców, wzrost zachowań } \\
\text { agresywnych wśród dziewcząt i wobec nich. }\end{array}$ \\
\hline Przemoc domowa & $\begin{array}{l}\text { Informacje pochodzą ze statystyk policyjnych oraz dekla- } \\
\text { racji dzieci uczestniczących w badaniach randomizowa- } \\
\text { nych. Przemoc wobec dzieci przejawiają głównie ojcowie } \\
\text { i inni opiekunowie, występuje ona wraz z przemocą wo- } \\
\text { bec kobiety. }\end{array}$ \\
\hline Niebezpieczna szkoła & $\begin{array}{l}\text { Informacje pochodzą ze sprawozdawczości administracji } \\
\text { publicznej. Wzrost urazów na terenie szkoły. }\end{array}$ \\
\hline $\begin{array}{l}\text { Ograniczona edukacja zdrowotna mło- } \\
\text { dzieży, brak dostępu do poradnictwa } \\
\text { oraz ochrony zdrowia }\end{array}$ & $\begin{array}{l}\text { Informacje pochodzą z raportów administracji publicznej } \\
\text { oraz NGOs. Wnioski: nieświadomość skutków ryzykow- } \\
\text { nych zachowań zdrowotnych i nonszalancja wobec ryzyka. }\end{array}$ \\
\hline
\end{tabular}

Źródło: zestawienie własne oparte głównie na wynikach badań HBSC (WHO 2008b). 
Wśród zewnętrznych przyczyn zgonów młodych ludzi, niezwykle bolesną przyczyną są samobójstwa. Częściej popełniają je chłopcy niż dziewczęta. W krajach postkomunistycznych samobójstwa młodych mężczyzn zdarzają się częściej niż w krajach starej Europy (z wyjątkiem Finlandii). Wskaźnik samobójstw chłopców w wieku 15-19 lat w przeliczeniu na 100 tys. osób w tym wieku jest w Polsce w dłuższym okresie niezmienny, kształtuje się na relatywnie wysokim poziomie (15 przypadków). Spośród nowych krajów członkowskich UE tylko na Litwie (27) oraz w Estonii (20) jest większy niż w Polsce (Menchini, Marnie, Tiberti 2009).

Jak wynika z badań HBSC, 15-latki w Polsce znacznie rzadziej uczestniczą w bójkach, które przynoszą im szkody zdrowotne, niż młodzież w innych krajach europejskich. Częściej natomiast zdarza się chłopcom pobić innych w szkole i w tym rankingu sytuują się powyżej przeciętnej (18\% wobec $12 \%$ ). Polskie badania sugerują wzrost wśród dziewcząt zachowań agresywnych (Diagnoza Społeczna 2007), nazwanych męskimi zachowaniami młodych kobiet. Wyjaśnia się to $z$ jednej strony dosłownym rozumieniem równouprawnienia płci, a $z$ drugiej zaniedbaniami wychowawczymi pokolenia transformacji ${ }^{5}$. Ta tendencja wzrostowa nadal nie niweluje jednak znacznej różnicy w tym względzie między chłopcami i dziewczętami. Chłopcy ciągle zdecydowanie częściej demonstrują zachowania agresywne i stosują przemoc, także wobec dziewcząt.

Wśród innych wskaźników ryzykowanych zachowań zdrowotnych wartość wyższą niż przeciętnie w krajach UE ma wskaźnik sięgania po marihuanę. Narkotyki są coraz częściej dostępne na młodzieżowych imprezach i bywają zażywane $\mathrm{w}$ grupach. Zaczęły się pojawiać w szkole, oferowane przez dilerów w jej pobliżu. Problem zażywania narkotyków przez młodzież stał się palący, a jednocześnie wystapiły znaczace kontrowersje co do sposobów jego zwalczania - dyskutujący wahają się między prohibicją i ostrymi karami więzienia a legalizacją narkotyków miękkich.

Inicjacja alkoholowa i palenie papierosów nie wyróżnia negatywnie polskiej młodzieży na tle innych krajów UE. Relatywnie niekorzystny dla Polski jest wskaźnik pierwszego upicia się w wieku 13-14 lat (ESPAD 2007), a przy tym wysoki udział dziewcząt w tych doświadczeniach. Dane statystyczne o zachowaniach młodzieży starszej wskazują, że sięganie po napoje alkoholowe jest bez mała powszechne, chociaż wskaźniki pochodzące $z$ badań autorskich są zróżnicowane: od 50\% do 100\% (Binkowska-Bury 2009). Na ogół dotyczy to piwa i wina, zwłaszcza wśród młodzieży akademickiej, co nieco łagodzi obraz, jako że jeszcze kilkanaście lat temu znacznie częściej sięgano po mocne alkohole.

5 W tygodniku „Polityka” w 2005 r. Martyna Budna przygotowała na ten temat raport, który ukształtował nieco przesadzony obraz agresji dziewcząt, ale wywołał bardzo potrzebną w Polsce dyskusję o warunkach życia młodzieży $\mathrm{w}$ okresie transformacji, z powszechnym wówczas bezrobociem, pracą w szarej strefie oraz emigracją zarobkową rodziców. 
Naturalne i „zewnętrzne” przyczyny zgonu ludzi młodych (15-19 lat) w krajach Europy Środkowej i Wschodniej

\begin{tabular}{|l|c|c|}
\hline \multirow{2}{*}{ Kraje } & Wskaźnik umieralności młodzieży (na 100 tys. osób w odpowiednim wieku) \\
\cline { 2 - 3 } & $\begin{array}{c}\text { z powodu wypadków, urazów } \\
\text { i samobójstw }\end{array}$ & z powodów naturalnych \\
\hline Rosja & 86 & 29 \\
Kazachstan & 70 & 38 \\
Litwa & 61 & 17 \\
Estonia & 54 & 15 \\
Białoruś & 53 & 17 \\
Ukraina & 51 & 25 \\
Eotwa & 42 & 18 \\
Chorwacja & 33 & 14 \\
Polska & 32 & 14 \\
Słowenia & 31 & 12 \\
Czechy & 30 & 12 \\
Węgry & 24 & 17 \\
Słowacja & 24 & 15 \\
Bułgaria & 24 & 23 \\
\hline
\end{tabular}

Źródło: UNICEF 2009.

Informacje o ryzykownych zachowaniach seksualnych młodych ludzi w Polsce są skromne. Badania HBSC informują, że w latach dziewięćdziesiątych znacznie obniżył się wiek inicjacji seksualnej. W następnej dekadzie wskaźnik ten wzrasta, choć $z$ uwagi na zmiany metodologiczne nie ma $\mathrm{w}$ tym względzie pewności. Zmniejszenie wskaźników występowania wczesnych doświadczeń seksualnych jest kojarzone $z$ oddziaływaniem na wzrost wstrzemięźliwości seksualnej uczniów szkolnego programu "wychowanie do życia w rodzinie” (Grzelak 2009, s. 140).

Istotnym czynnikiem zagrożenia zdrowia jest nieprawidłowe odżywianie się. Zachowania młodzieży $\mathrm{w}$ tej dziedzinie zależą nie tylko od nawyków żywieniowych $\mathrm{w}$ domu, ale także od oferty żywieniowej w szkole oraz $\mathrm{w}$ innych miejscach, w których jedzą uczniowie i studenci. Oferta ta w ciągu ostatnich lat stała się bogatsza, ale pozytywne efekty zdrowotne tego nie są oczywiste. Nadmiernie bowiem korzysta się z jedzenia typu fast-food, powszechne jest spożywanie przekąsek (często zamiast regularnego posiłku) bogatych w cukry i tłuszcze oraz nagminne sięganie po słodkie napoje, łatwo dostępne, także w szkolnych kioskach. Jednocześnie zaniedbaniu uległ zwyczaj codziennego pierwszego śniadania w domu i zabierania drugiego śniadania do szkoły. Badania prowadzone $\mathrm{w}$ długim okresie w Warszawie dowodzą, że spożywanie przez uczniów drugiego śniadania systematycznie maleje (Wajszczyk 2008).

Znaczący wpływ na zdrowie mają także inne aspekty stylu życia, a wśród nich aktywność fizyczna. Młodzież uprawiająca sport i systematycznie zaży- 
wająca ruchu zachowuje się przy tym także prozdrowotnie $\mathrm{w}$ dziedzinie odżywiania się i rzadziej sięga po używki (Binkowska-Bury 2009). Z badań HBSC wynika, że polska młodzież jest generalnie mało aktywna fizycznie. Wśród 15-latków ćwiczenia fizyczne przez co najmniej godzinę dziennie uprawiało $21 \%$ badanych chłopców oraz tylko $10 \%$ dziewcząt. Uprawianie sportu i zażywanie ruchu jest $\mathrm{w}$ wysokim stopniu zależne od poziomu dobrobytu rodziny. W rodzinach zamożniejszych znacznie częściej przywiązuje się doń wagę. Gdy infrastruktura aktywności fizycznej jest nierozwinięta i/lub dla biedniejszych dzieci niedostępna, to w rezultacie uzyskuje się niekorzystną dla społecznego rozwoju korelację. Inna prawidłowość polega na zmniejszaniu się aktywności fizycznej wraz z wiekiem, na co wpływ ma także brak urządzeń sportowo-rekreacyjnych na polskich uczelniach.

Rewersem wskaźników niskiej aktywności fizycznej młodzieży są wysokie wskaźniki oglądania telewizji. Więcej niż dwie godziny dziennie w ciągu tygodnia przed telewizorem spędzało w Polsce $69 \%$ badanych chłopców oraz $64 \%$ dziewcząt. Im rodzina była mniej zamożna, tym częściej młodzi ludzie spędzali czas na oglądaniu telewizji (WHO 2008b). Ta prawidłowość przenosi się na różnice między krajami w Europie. Młodzież z biedniejszego regionu Europy Środkowej i Wschodniej częściej niż młodzież z krajów Europy Zachodniej spędza czas przed telewizorem i komputerem.

Syntetycznym wskaźnikiem odzwierciedlającym wady odżywiania oraz słabą aktywność fizyczną jest wskaźnik otyłości. Problem otyłości wśród młodzieży w Polsce nie jest tak poważny jak w innych krajach europejskich. Ciągle jeszcze niedowaga, a nawet niedożywienie, występuje w podobnej skali jak otyłość. Niedowaga dotyczy zwłaszcza dziewcząt, które przy tym są znacznie mniej aktywne fizycznie niż chłopcy. Ponieważ duże znaczenie ma dla nich motywacja związana $z$ estetyką ciała, za niską wagę jest odpowiedzialne także niedojadanie, co może być przyczyną takich chorób jak anoreksja i bulimia. Badania wśród 18-letnich uczennic wskazały, że silnym czynnikiem zagrożenia tymi chorobami jest nie tylko wadliwe odżywianie się, ale również brak akceptacji dla własnego ciała (Lwow, Dunajska, Milewicz 2007). Silny wpływ na takie podejście mają media i kult sylwetki modelki.

Wśród zagrożeń zdrowia młodzieży coraz większą rolę odgrywają czynniki środowiskowe. Ich negatywny wpływ może zniwelować przede wszystkim dobra szkoła i rodzina, czyli wykształceni, zamożniejsi oraz świadomi znaczenia zachowań prozdrowotnych rodzice, a także czas, jaki rodzice mogą poświęcić swym nastoletnim dzieciom, dobrze się z nimi komunikując. Wiadomo jednak, że młodzież, także $z$ „dobrych" rodzin, coraz częściej i dłużej przebywa $\mathrm{w}$ otoczeniu zewnętrznym i w szkole. Od tego, czy warunki zewnętrzne są bezpieczne, jaka jest infrastruktura, jakie pod względem zdrowotnym usługi są oferowane, jakie wzorce promowane, jaka atmosfera dominuje (przyjazna czy stres), w zasadniczym stopniu zależy zdrowie młodych ludzi, i to nie tylko w okresie młodzieżowym, ale także później. Inwestycja w zdrowie wymaga 
więc znacznie większych niż dotychczas nakładów na zdrowe otoczenie młodzieży w Polsce. Braki bezpiecznej i dostosowanej dla potrzeb młodzieży infrastruktury, brak edukacji zdrowotnej w szkole, brak kontroli produktów i usług oferowanych młodzieży, ograniczony dostęp do opieki i doradztwa lekarskiego w szkole - wszystko to uderza głównie w dzieci rodziców niezamożnych i słabiej wykształconych, przyczyniając się do kumulacji niekorzystnych czynników ich rozwoju.

\section{ZAGROŻENIA NA TLE ZABURZEŃ RELACJI RODZINNYCH I SPOŁECZNYCH MŁODZIEŻY}

Dojrzewanie to w życiu człowieka okres szczególnej wrażliwości na wpływy pozarodzinne. Rola rodziców ulega osłabieniu i od ich umiejętności wychowawczych oraz więzi w rodzinie zależy, czy potrafią nadal, choć inaczej, sprawować kontrolę nad rozwojem dorastających dzieci.

Wyniki badań nad relacjami między rodzicami i dziećmi w okresie dojrzewania ukazują skomplikowany i dynamiczny obraz trudności. Dostrzeżone prawidłowości są następujące. W okresie dorastania pojawiają się istotne trudności w komunikacji z rodzicami, większe $z$ ojcem niż matką i rosnące wraz $z$ wiekiem nastolatków. Lepsze porozumienie $z$ ojcem mają chłopcy niż dziewczęta i jest ono większe w rodzinach zamożniejszych, w których rodziców cechuje też wyższy poziom kompetencji. Polskie nastolatki lepiej porozumiewają się z rodzicami niż przeciętnie w innych krajach europejskich, ale różnica między komunikacją z ojcem i matką jest u nas większa, na korzyść matki (WHO 2008b).

Polskie badania na temat relacji z rodzicami, których przegląd znajdujemy w pracy Edyty Mianowskiej (2008), sugerują, że mimo przekonania o uczuciach i trosce rodziców narzekanie dzieci na brak zrozumienia ich potrzeb i problemów jest bez mała powszechne. Nadopiekuńczość, nierespektowanie rosnącej potrzeby niezależności, rygoryzm i przykładanie nadmiernego znaczenia do wyników w szkole w stosunku do innych osiągnięć dziecka oraz niedocenianie zajęć w czasie wolnym - to główne grzechy polskich rodziców. W tych rodzinach, w których rodzice potrafią zmieniać się pod wpływem dorastających dzieci i umiejętnie wychodzić naprzeciw ich nowym i naturalnym potrzebom większej wolności (nazywanych rodzinami partnerskimi), konflikty i trudne problemy są zdecydowanie mniejsze. Są natomiast istotnie większe, gdy relacje między rodzicami są gorsze lub gdy pojawia się zagrożenie spójności rodziny na skutek nieobecności któregoś z rodziców, na przykład emigracji zarobkowej, separacji czy rozwodu.

Dzieci w okresie dojrzewania traumatycznie przeżywają rozstania rodziców i z rodzicami, tracą poczucie bezpieczeństwa, mają trudności w szkole i kłopoty $z$ wytyczeniem własnej drogi życiowej. Jest to jedna z poważniejszych przyczyn samobójstw, których społeczny mechanizm w powiązaniu $z$ relacjami w ro- 
dzinie opisał już Émile Durkheim. Współczesne badania nad samobójstwami młodzieży sygnalizują związek wskaźników takich zachowań z wychowaniem $\mathrm{w}$ rodzinie niepełnej i $z$ nieobecnością ojca $\mathrm{w}$ rodzinie (Bjarnason i in. 2004).

Statystyki demograficzne wskazują, że rozwody i separacje są w Polsce relatywnie rzadkie, chociaż występuje tendencja rosnąca, która dotyczy zwłaszcza małżeństw z krótkim stażem. Istotny wpływ na utrzymanie spójności rodziny oraz poczucie bezpieczeństwa dzieci ma nieobecność rodziców (rodzica) z powodu emigracji zarobkowej. Zjawisko opuszczenia dzieci na skutek wyjazdu do pracy w zjednoczonej Europie (eurosieroctwo) występuje także w innych krajach nowej emigracji, na przykład w Rumunii.

Dramatycznych trudności życiowych doświadcza młodzież wychowująca się $\mathrm{w}$ rodzinach $z$ dysfunkcjami, głównie $z$ chorobą alkoholową rodzica (-ców), innymi uzależnieniami, przemocą domową, nierządem, uczestnictwem $\mathrm{w}$ działaniach przestępczych itd. Jeśli dziecko będzie umiało zbudować sobie świat innych odniesień i pozytywnych emocji, zwłaszcza gdy poda mu się pomocną dłoń, aby taki świat znalazło i zaakceptowało, to może nie ulec destrukcyjnym wpływom własnej rodziny. Inną drogą wyjścia z trudności jest terapia i edukacja rodziców; można wówczas uratować całą rodzinę. Jest to jednak droga znacznie trudniejsza, do której instytucje pomocy rodzinie w Polsce nie są jeszcze przygotowane.

Zestawienie 2

Zagrożenia rozwoju emocjonalnego i społecznego młodzieży w kontekście relacji w rodzinie

\begin{tabular}{|l|l|}
\hline \multicolumn{1}{|c|}{ Obszary zagrożeń } & \multicolumn{1}{|c|}{ Wskaźniki i tendencje } \\
\hline Brak rodziny & $\begin{array}{l}\text { Wskaźnik młodzieży wychowywanej w instytucjach; } \\
\text { w placówkach opiekuńczo-wychowawczych w Polsce } \\
\text { wychowuje się relatywnie więcej nastolatków niż w kra- } \\
\text { jach Europy Zachodniej. }\end{array}$ \\
\hline $\begin{array}{l}\text { Brak porozumienia między rodzicami } \\
\text { i dziećmi }\end{array}$ & $\begin{array}{l}\text { Rośnie wraz wiekiem dziecka i zależy od zamożno- } \\
\text { ści rodziny; w rodzinach zamożniejszych komunikacja } \\
\text { z dziećmi jest lepsza. }\end{array}$ \\
\hline $\begin{array}{l}\text { Dysfunkcyjna rodzina; choroba alkoho- } \\
\text { lowa i inne uzależnienia rodziców, nie- } \\
\text { podejmowanie pracy, rozwiązły styl życia } \\
\text { grożenie powielaniem wzorów życia rodziców, zagro- } \\
\text { żenie przestępczością i pobytem w zakładach karno- } \\
\text {-wychowawczych. }\end{array}$ \\
\hline $\begin{array}{l}\text { Kryzys w rodzinie: rozstanie i rozwód ro- } \\
\text { dziców }\end{array}$ & $\begin{array}{l}\text { Wskaźnik rozwodów w Polsce ma niski poziom, ale ten- } \\
\text { dencja jest wzrostowa, podobnie jak w innych krajach } \\
\text { UE; negatywny wpływ na zdrowie psychiczne i na osią- } \\
\text { gnięcia szkolne. }\end{array}$ \\
\hline Wczesne macierzyństwo & $\begin{array}{l}\text { Nastoletnie matki; urodzenia pozamałżeńskie wśród } \\
\text { młodych matek. }\end{array}$ \\
\hline Późne usamodzielnianie się & $\begin{array}{l}\text { Wiek wyjścia z domu - usamodzielnienia; trudności } \\
\text { ze stworzeniem własnej rodziny w przyszłości. }\end{array}$ \\
\hline
\end{tabular}

Źródło: zestawienie własne. 
W rodzinie z problemami „lepszych” relacji emocjonalnych młodzież poszukuje poza rodziną. Wcześnie podejmuje życie seksualne, czego konsekwencją bywa nastoletnie macierzyństwo i rodzicielstwo. Informacje o wczesnym macierzyństwie, pochodzące $z$ europejskiego badania panelowego gospodarstw domowych (ECPH), wskazują, że podstawowe zmienne skorelowane $z$ tym zjawiskiem to: ubóstwo, niski poziom wykształcenia rodziców młodocianej matki (a zwłaszcza jej matki), wychowanie w niepełnej rodzinie oraz ograniczone zatrudnienie rodziców: bierność zawodowa, bezrobocie, niestabilna praca (Robson, Berthoud 2003). Zależności te potwierdzają wyniki badań na temat zdrowia reprodukcyjnego, których przegląd został wykonany na zlecenie Komisji Europejskiej ${ }^{6}$. Wpływ czynników społeczno-demograficznych, deprywacja, niestabilność rodziny oraz ryzykowny styl życia - to główne czynniki potwierdzone w wielu badaniach krajów europejskich. Do wymienionych zmiennych autorzy raportów krajowych dołączają brak edukacji zdrowotnej i seksualnej wśród nastolatków (Imamura $\mathrm{i}$ in. 2007).

Wśród krajów UE na czele statystyk wczesnego macierzyństwa sytuuje się Wielka Brytania. Polskie nastolatki wczesnymi rodzicami stają się rzadziej niż przeciętnie w krajach europejskich. Nie ma zbyt wielu studiów na ten temat (najczęściej sięga się po demograficzne analizy Wiktorii Wróblewskiej, prowadzone na podstawie danych ze spisów powszechnych oraz badań opinii), chociaż problem jest nagłaśniany przez media.

Wczesne macierzyństwo zdarza się także w tzw. dobrych domach, ale wtedy zagrożenie jakości dalszego życia młodej matki (głównie przez przerwanie edukacji) i jej dziecka nie jest duże. Zwykle pomagają rodzice, biorąc na siebie trud wychowania wnuka i wspierając młodocianych rodziców w dalszym kształceniu. Natomiast w rodzinach o słabych więziach emocjonalnych i dysfunkcyjnych młoda matka także skazuje się na dysfunkcyjne życie, bo często nie ma szans na dalszą edukację i stabilną pracę. Niejednokrotnie próbuje stworzyć swoją rodzinę, ale środowisko, w którym żyje, ogranicza wybór właściwego partnera oraz szanse na stworzenie „normalnej” rodziny. Powtarza się zmiana partnerów, pojawiają się kolejne dzieci i bezradność w ich wychowywaniu. Gdy towarzyszy temu nadużywanie alkoholu oraz przemoc domowa, dzieci umieszczane są w instytucjach wychowawczych.

Do instytucji opiekuńczo-wychowawczych trafiają głównie dzieci z rodzin dysfunkcyjnych (znacznie rzadziej z powodu braku rodziców). Nazywane są sierotami społecznymi w odróżnieniu od sierot naturalnych. Najczęściej przebywają tam przez całe dzieciństwo ${ }^{7}$. Wskaźnik dzieci wychowywanych w insty-

\footnotetext{
${ }^{6}$ Przegląd ten znany jako REPROSTAT 2, objął także nowe kraje członkowskie UE (Imamura $\mathrm{i}$ in. 2007).

7 W placówkach opiekuńczo-wychowawczych, które obecnie znajdują się w kompetencji Ministerstwa Pracy i Polityki Społecznej (a nie Ministerstwa Edukacji, jak było wcześniej), przebywa
} 
tucjach do zakończenia siedemnastu lat w przeliczeniu na 100 tys. dzieci w tym wieku jest relatywnie wysoki - 726, gdy na Węgrzech dwukrotnie niższy, ale na Litwie - dwukrotnie wyższy (Menchini, Marnie, Tiberti 2009). Alternatywne formy, a przede wszystkim system adopcyjny oraz rodzin zastępczych, ciągle są w Polsce mało efektywne mimo kampanii społecznych i akcji medialnych na rzecz przyjmowania dzieci z domów dziecka. Domy dziecka mają złą opinię, choć w przypadku polskich placówek nie zawsze jest ona zasłużona ${ }^{8}$.

Powstałych deficytów rozwojowych nie jest w stanie zrekompensować nawet najlepsza instytucja opiekuńczo-wychowawcza. Przyszłość dzieci jest wówczas zagrożona, ponieważ brak wyposażenia w kapitał emocjonalny, kompetencyjny i materialny grozi ubóstwem i społecznym wykluczeniem na jakimś etapie dorosłego życia. Badania losów wychowanków domów dziecka oraz ośrodków szkolno-wychowawczych, prowadzone w ramach projektu „Polska bieda III” (Giermanowska, Racław-Markowska 2007), sygnalizują poważne trudności $z$ ich wchodzeniem $w$ dorosłość. Życie dzieci z domów dziecka już na początku jest naznaczone społecznym wykluczeniem. $\mathrm{Z}$ tego powodu $\mathrm{w}$ wielu krajach, także w Polsce, wprowadza się programy adresowane do wychowanków domu dziecka, mające pomóc im wejść w dorosłe życie. Młodzież z domów dziecka potrzebuje bowiem „doradcy” w procesie usamodzielniania i jednocześnie łącznika $z$ ich nowym światem.

W okresie dojrzewania, gdy wzrasta oddziaływanie świata zewnętrznego, istotną rolę pełni grupa rówieśnicza. Psychologowie i inni badacze społeczni przypisują temu ogromne znaczenie dla ukształtowania prawidłowego rozwoju społecznego i emocjonalnego dziecka (zob. Mianowska 2008). Rówieśnicy stają się niekiedy odniesieniem o znacznie większym wpływie na kształtowanie osobowości niż rodzina oraz szkoła. Grupy rówieśnicze są jednak różne ${ }^{9}$. Jeśli grupa rówieśnicza jest progresywna, co oznacza, że młodzi ludzie wspierają się co do podobnych celów, zainteresowań i wartości, to staje się niezwykle korzystnym zasobem rozwoju dziecka. Gdy jednak celem grupy jest głównie rozrywka, ryzykowne eksperymenty z używkami i prowokacyjne zachowania wobec wybranych dorosłych, jej wpływ na rozwój jest niebezpieczny. Akceptacja ryzykownych i aspołecznych zachowań członków nie musi być w grupie całkowita. Istnieje jednak pewien typ zachowań, które są traktowane jako dopuszczalne. Należy do nich wagarowanie, palenie papierosów i picie alkoholu (z badań zielonogórskich gimnazjalistów; Mianowska 2008).

około 30 tys. dzieci i młodzieży. Co roku około 6000 tys. dzieci czeka na miejsce. Rozwój innych form opieki jest wysoce niedostateczny (z raportu ZNP 2002 i 2007).

8 W krajach Europy Środkowej i Wschodniej w sensie instytucjonalnym istniał podobny system opieki nad społecznymi i naturalnymi sierotami. Dramatycznie złe warunki przebywania w domach dziecka w takich krajach jak Rosja, Ukraina czy Rumunia zostały opisane w wielu raportach, głównie UNICEF (Carter 2005).

${ }^{9}$ Ich typologie przedstawia Anna Frindt (2005). 
Podobnie jak w szkole podstawowej, tak i w gimnazjach lekceważenie obowiązków szkolnych, papierosy i alkohol stanowią plagę środowisk uczniowskich.

Silne grupy rówieśnicze nie są jednak wśród polskiej młodzieży dominującym modelem relacji społecznych. Z cytowanych już wielokrotnie badań HBSC (WHO 2008b) wynika, że polska młodzież $\mathrm{w}$ porównaniu $\mathrm{z}$ rówieśnikami $z$ innych krajów znacznie rzadziej przynależy do jakiejś paczki, definiowanej jako grupa co najmniej trzech przyjaciół, i znacznie rzadziej spędza wolny czas z przyjaciółmi w ciągu tygodnia. Jeżeli na przykład w krajach skandynawskich młodzi ludzie mają bez mała powszechnie przyjaciół tej samej płci, to w Polsce tylko 50\% badanych; częściej chłopcy (ponad 60\%) niż dziewczęta. Polskie 15-latki częściej natomiast kontaktują się z przyjaciółmi za pomocą środków elektronicznych.

$\mathrm{Z}$ międzynarodowych badań porównawczych wynika, że posiadanie większej liczby przyjaciół i spędzanie $z$ nimi czasu jest silnie skorelowane $z$ poziomem życia rodziny. Zamożniejsza młodzież i w zamożniejszych krajach bardziej jest nastawiona na bezpośrednie kontakty rówieśnicze (WHO 2008b). Polskie badania nie potwierdzają całkowicie tej prawidłowości (Mianowska 2008), ale dane są za skromne, aby można było na nich polegać.

Pozaszkolna aktywność młodzieży

\begin{tabular}{|l|l|}
\hline \multicolumn{1}{|c|}{ Rodzaje społecznej aktywności } & \multicolumn{1}{|c|}{ Miary, wskaźniki i wyniki badań } \\
\hline Krąg przyjaciół & $\begin{array}{l}\text { Przynależność do paczki } \\
\text { Spędzanie czasu z kolegami } \\
\text { Kontakty elektroniczne } \\
\text { Spędzanie czasu „na ulicy” }\end{array}$ \\
\hline $\begin{array}{l}\text { Aktywność w organizacjach sporto- } \\
\text { wych }\end{array}$ & $\begin{array}{l}\text { Przynależność do organizacji sportowych; relatywnie wy- } \\
\text { soka w starych krajach UE (deklaruje około 50\%), niska } \\
\text { w Polsce - 26\% }\end{array}$ \\
\hline Działalność społeczno-polityczna & $\begin{array}{l}\text { Przynależność do organizacji: } \\
\text { - społecznej - deklaruje 22\% młodych Europejczyków, } \\
\text { - politycznej i związkowej - 4\% }\end{array}$ \\
\hline $\begin{array}{l}\text { Wolontariat i zaangażowanie w prace } \\
\text { na rzecz wspólnoty lokalnej }\end{array}$ & $\begin{array}{l}\text { Okazjonalny wolontariat deklaruje 16\% młodych Euro- } \\
\text { pejczyków, ale trwałe zaangażowanie tylko 2\% }\end{array}$ \\
\hline Aktywność w organizacjach religijnych & $\begin{array}{l}\text { Członkostwo i uczestnictwo młodzieży w organizacjach } \\
\text { religijnych - wskaźniki dla Polski wyższe niż przeciętne } \\
\text { dla UE }\end{array}$ \\
\hline $\begin{array}{l}\text { Aktywność w organizacjach artystycz- } \\
\text { nych i naukowych }\end{array}$ & $\begin{array}{l}\text { Przynależność i uczestnictwo młodzieży w organizacjach } \\
\text { artystycznych i naukowych - w Polsce nieco wyższe niż } \\
\text { przeciętnie w krajach europejskich (10\% wobec 8\%) }\end{array}$ \\
\hline Hobby & $\begin{array}{l}\text { Uczestnictwo młodzieży w kołach i klubach hobbystycz- } \\
\text { nych: wskaźniki dla Polski takie jak przeciętne w UE }\end{array}$ \\
\hline
\end{tabular}

Źródło: WHO 2008b; Eurobarometr 2007; Eurostat 2009. 
Społeczny rozwój młodzieży zależy także od możliwości i warunków uczestnictwa w zorganizowanych formach życia pozaszkolnego. Polska młodzież tradycyjnie uczestniczy w organizacjach harcerskich, działalności duszpasterskiej, klubach sportowych oraz w różnych kołach zainteresowań: artystycznych, naukowych czy hobbystycznych. Podejmuje też działalność socjalną (jako wolontariusze) w organizacjach pozarządowych. Dostęp do tych aktywności nie jest powszechny. W dużych miastach znacznie większy niż w małych i na wsi. Z europejskich badań na ten temat wynika, że młodzi Polacy, podobnie jak inni młodzi ludzie z nowych krajów członkowskich, relatywnie częściej należą do organizacji młodzieżowych, a dwukrotnie rzadziej do klubów czy kół sportowych.

W starej Europie główne zajęcia pozaszkolne młodzieży — to zajęcia sportowe. Do różnego rodzaju organizacji sportowych w UE-15 należy przeciętnie $52 \%$ badanych w wieku $15-30$ lat, a w Niemczech nawet $71 \%$, gdy w Polsce zaledwie $26 \%$ (Eurobarometr $2007^{10}$ ). Ten wskaźnik powinien zdecydowanie uzasadnić potrzebę większej troski o aktywność fizyczną młodych ludzi w Polsce, znacznie większej niż dotychczas ${ }^{11}$.

Młodzi ludzie w Polsce nie włączają się do działalności politycznej, z rzadka także - do socjalnej, aby uczestniczyć jako wolontariusze w organizacjach pozarządowych. W wielu krajach starej Europy nie jest dużo lepiej, z wyjątkiem krajów skandynawskich, gdzie uczestnictwo polityczne i społeczne jest relatywnie bardzo wysokie, na przykład w Danii 55\% młodych ludzi należy do związków zawodowych.

Brak społeczno-politycznego zaangażowania młodych ludzi w ogólniejsze problemy swego kraju i Europy, a także swego regionu, stanowi przedmiot troski wielu polityków i ekspertów, którzy nie tylko promują specjalnie przygotowane programy edukacyjne i kampanie motywujące do aktywności społecznej, politycznej oraz ekologicznej u siebie ${ }^{12}$, ale też nawołują do większej aktywności na rzecz propagowania europejskich koncepcji społecznych.

\section{ZAGROŻENIA ROZWOJU W SFERZE EDUKACJI}

Pełne uczestnictwo w dobrej i dostosowanej edukacji jest podstawą sukcesu w dalszym życiu. Dlatego brak dostępu do szkół, trudności szkolne oraz wypa-

10 Raport Komisji Europejskiej w ramach Eurobarometru o aktywności społecznej młodych ludzi powstał na podstawie badania Gallupa pt. Youth survey among people aged between 15-30 years age, in the 27 Member States, przeprowadzonego na początku 2007 r. wśród 19000 wylosowanych młodych Europejczyków.

11 Jaskółką zmian korzystnych dla aktywności fizycznej nastolatków jest rządowy program budowy boisk sportowych Orlik 2012.

12 Programy takie rozwijane są zwłaszcza w Wielkiej Brytanii. Jeśli chodzi o kształtowanie wrażliwości na kwestie socjalne, wprowadzono tam program rozwoju wolontariatu nazwany vinvolved, wspierając go grantami i nagrodami, które promują aktywność społeczną wśród młodzieży w wieku 16-25 lat. 
danie $z$ systemu szkolnego stanowią podstawowe zagrożenia $\mathrm{w}$ tej dziedzinie, skutkujące gorszą drogą życiową, a nawet wypadaniem z tzw. głównego nurtu życia społecznego, czyli społecznym wykluczeniem.

Zagrożenia rozwoju edukacyjnego opisywane są przez wiele wskaźników, zaproponowanych przez ekspertów organizacji międzynarodowych zajmujących się problematyką edukacyjną: OECD (Education at Glance i PISA), UNESCO oraz Komisję Europejską (2004), a także promowanych przez poszczególne kraje jako tzw. dobre praktyki. W zestawieniu 4 dokonano wyboru tych, które ewidentnie wskazują na ograniczenia rozwoju młodzieży, a jednocześnie posłużyły do stworzenia bogatych baz danych i opracowania raportów pozwalających na diagnozowanie sytuacji krajowych oraz na międzynarodowe porównania.

Zagrożenia związane $z$ edukacją, opisane $z$ wykorzystaniem stosowanych miar i wskaźników oraz odpowiadających im i dostępnych danych statystycznych, mają wiele wymiarów. Można je podzielić na następujące grupy:

- związane $z$ ograniczonym dostępem do edukacji,

— związane ze złymi warunkami działania szkół; infrastrukturalnymi, finansowymi, kadrowymi, organizacyjnymi,

- związane z niskim poziomem osiągnięć edukacyjnych młodzieży,

- związane $z$ niedostosowaniem programów nauczania i rodzajów szkół do potrzeb rynku pracy,

- związane z brakiem wsparcia socjalnego dla uczącej się młodzieży.

W odniesieniu do pierwszej grupy zagrożeń, w zakresie dostępu do edukacji, stosowane są wskaźniki skolaryzacji, które informują o uczestnictwie młodzieży w szkołach kolejnych poziomów. Uczestnictwo w edukacji podstawowej jest $\mathrm{w}$ krajach europejskich obowiązkowe i od wielu dziesiątków lat powszechne, a więc $w$ tej dziedzinie przedmiotem monitorowania oraz analizy są głównie sytuacje wypadania $z$ systemu szkolnego. W UE został zaproponowany wskaźnik wczesnego wypadania z systemu szkolnego (early school leaving), nazywany niekiedy odpadem szkolnym.

Dane statystyczne OECD oraz Eurostatu (OECD 2004; European Commission 2005) informują, że wczesne opuszczenie szkoły w okresie obowiązku szkolnego (do 18-tu lat) w Polsce należy do rzadkości (5,5\%, czyli znacznie poniżej krytycznych 10\%). Wyniki statystyk międzynarodowych sytuują nasz kraj w tej dziedzinie na bardzo dobrej pozycji. Pogłębione analizy tego problemu sugerują jednak, że przypadki wypadania z systemu szkolnego nie są odosobnione. Można powiedzieć, że jest to raczej zjawisko ukrywane lub statystycznie łagodzone przez liberalny stosunek do problemu uczniów nie dających sobie rady z nauką lub nie uczęszczających do szkoły regularnie ( $z$ dużą absencja). Pełnie rozpoznanie zjawiska jest słabe. Istnieją tylko sygnały pochodzące z badań jakościowych oraz kontroli NIK (np. NIK 2003). Wynika z nich, że szkoły nie mają motywacji, aby raportować występowanie trudnych sytuacji (przeciwnie - na przykład subwencja oświatowa zależy od liczby uczęszczają- 
Zagrożenia rozwoju młodzieży w sferze edukacji

\begin{tabular}{|c|c|}
\hline Obszary zagrożeń & Miary, wskaźniki, kierunki wpływu \\
\hline $\begin{array}{l}\text { Niepełne uczestnictwo w edukacji na } \\
\text { poziomie średnim i wyższym }\end{array}$ & $\begin{array}{l}\text { Wskaźnik skolaryzacji na poziomie średnim i wyższym; } \\
\text { w krajach UE około } 80 \% \text { osób w wieku } 25-29 \text { ma ukoń- } \\
\text { czoną szkołę średnią, studiuje około } 12 \% \text { osób w wieku } \\
\text { 18-29 lat; w Polsce - ogromny wzrost udziału młodzieży } \\
\text { idącej na studia, w latach } 1995-2007 \text { podwójny. }\end{array}$ \\
\hline Niska jakość funkcjonowania szkoły & $\begin{array}{l}\text { Wydatki na edukację: niedostateczne dofinansowanie } \\
\text { szkół w biednych gminach. } \\
\text { Kwalifikacje nauczycieli; udział nauczycieli z wyższym } \\
\text { specjalistycznym wykształceniem w ogólnej liczbie na- } \\
\text { uczycieli; wzrost formalnych wymagań w Polsce. } \\
\text { Rozmiar klas; liczba uczniów na nauczyciela. }\end{array}$ \\
\hline $\begin{array}{l}\text { Krótki okres przebywania w systemie } \\
\text { szkolnym }\end{array}$ & $\begin{array}{l}\text { Wskaźnik przeciętnego trwania edukacji (school life ex- } \\
\text { pectancy). }\end{array}$ \\
\hline $\begin{array}{l}\text { Opuszczający szkołę przed jej zakoń- } \\
\text { czeniem }\end{array}$ & $\begin{array}{l}\text { Wskaźnik early school leavers należy do zbioru wskaźników } \\
\text { proponowanych przez UE w ramach metody otwartej ko- } \\
\text { ordynacji (OMC), konstruowany dla wieku 15-19 i } 18 \\
-24 \text { lat; dla wieku } 18-24 \text { wynosi w krajach UE przeciętnie } \\
14,8 \% \text { (2007), a w Polsce } 5 \% \text {. }\end{array}$ \\
\hline Uzyskujący słabe wyniki nauczania & $\begin{array}{l}\text { Miary projektu PISA (Programme for International Student } \\
\text { Assessment) prowadzonego przez OECD od } 2000 \text { r.: (1) ro- } \\
\text { zumienie tekstów, (2) rozumowanie i umiejętności mate- } \\
\text { matyczne, (3) rozumowanie w naukach przyrodniczych, } \\
\text { (4) umiejętności rozwiązywania problemów. }\end{array}$ \\
\hline Nie uczący się języków obcych & $\begin{array}{l}\text { W krajach UE przeciętnie } 10 \% \text { młodych osób deklaruje, } \\
\text { że nie uczy się żadnego języka. }\end{array}$ \\
\hline $\begin{array}{l}\text { Nieumiejętność posługiwania się kom- } \\
\text { puterem i korzystania } z \text { internetu }\end{array}$ & $\begin{array}{l}\text { Dynamiczny wzrost codziennego używania komputera } \\
\text { i internetu wśród młodzieży. Osoby w wieku 16-24 maja } \\
\text { najwyższe wskaźniki korzystania w porównaniu z innymi } \\
\text { grupami wieku. Przeciętnie tylko } 7 \% \text { młodych osób w kra- } \\
\text { jach UE nie używa internetu. }\end{array}$ \\
\hline Dostęp do szkolnictwa zawodowego & $\begin{array}{l}\text { Indeks uczestnictwa młodzieży w kształceniu zawodo- } \\
\text { wym na poziomie średnim (VET). W nowych krajach } \\
\text { członkowskich, a wśród nich także w Polsce, oferta szkół } \\
\text { średnich zorientowanych zawodowo jest niedostateczna. }\end{array}$ \\
\hline $\begin{array}{l}\text { Brak lub skromny zakres systemu sty- } \\
\text { pendialnego }\end{array}$ & $\begin{array}{l}\text { System stypendialny w Polsce jest zróżnicowany i o ni- } \\
\text { skich świadczeniach. W krajach UE wsparcie stypendialne } \\
\text { młodzieży uczącej się jest na ogół słabe, rozwijany jest na- } \\
\text { tomiast system pożyczek i kredytów. }\end{array}$ \\
\hline
\end{tabular}

Źródło: zestawienie własne na podstawie danych OECD (2009b) oraz Komisji Europejskiej (2009).

cych uczniów), a presja dyrektorów szkół oraz władz oświatowych i samorządu terytorialnego na ich nieujawnianie jest silna (Zahorska 2009). Tymczasem wyniki badań nad szkolnictwem podstawowym i gimnazjalnym podejmowane 
w różnych miejscach kraju sugerują, że nieregularne uczęszczanie do szkoły jest w Polsce zjawiskiem poważnym; uczniowie relatywnie często wagarują, podejmując pracę zarobkową lub włączając się w zajęcia młodzieżowych grup "rozrywkowych" (gry komputerowe, picie piwa, przesiadywanie w galeriach handlowych, eksperymentowanie $z$ narkotykami). Są to dzieci rodziców nie tylko ubogich, ale także bardzo zajętych i z tego powodu zaniedbujących opiekę nad dziećmi (Wąsowska 2009, za: Zahorska 2009).

Istotnym czynnikiem przyszłych efektów inwestycji edukacyjnych są rezultaty nauczania. Do ich mierzenia zaczęto powszechnie wykorzystywać wskaźniki badania OECD (Programme for International Student Assessment PISA), które mierzą osiągnięcia uczniów gimnazjalnych (15-letnich) w czterech dziedzinach: (1) rozumienie tekstu, (2) rozumowanie i umiejętności matematyczne, (3) rozumowanie naukowe oraz (4) umiejętności rozwiązywania problemów ${ }^{13}$. Wyniki badań PISA w wielu krajach wywołały naukowe debaty na temat systemów edukacyjnych, roli nauczycieli oraz szkół w procesie nauczania (w Niemczech - Allmendinger, Leibfried 2003, w Wielkiej Brytanii Brook 2008). Doprowadziły w wielu przypadkach do potrzebnych a odkładanych reform edukacyjnych.

Wyniki badań PISA w odniesieniu do Polski wskazują, niezależnie od dziedziny, na trzy charakterystyczne tendencje: (1) usytuowanie na przeciętnych pozycjach wśród krajów OECD lub niewiele poniżej (za przeciętną przyjmuje się osiągniecie 500 punktów), (2) na duże zróżnicowanie wyników w przekroju pozycji społeczno-ekonomicznej rodziców i rodzajów szkół oraz (3) na tendencję poprawy wyników w kolejnych edycjach badań: 2000, 2003, 2006 (zob. tabela 2).

Najniższą pozycję $\mathrm{w}$ badaniach PISA polscy uczniowie uzyskali $\mathrm{w}$ dziedzinie matematyki; znacznie poniżej przeciętnej wśród raportujących krajów. Ten wynik zmienił nastawienie polskich ekspertów i polityków do programu nauczania matematyki, preferującego zaniżenie wymagań $z$ tego przedmiotu. W rezultacie w 2010 r. przywrócono matematykę jako obowiązkowy przedmiot egzaminu maturalnego. Osiągnięcia polskich gimnazjalistów powoli się poprawiają, chociaż wyniki są niższe niż przeciętne dla wszystkich krajów porównywanych w badaniu PISA.

Najsilniejszą tendencję wzrostową obserwuje się w dziedzinie określanej jako czytanie ze zrozumieniem. Tutaj został przekroczony poziom przeciętny i polscy uczniowie znaleźli się bliżej czołówki krajów OECD.

Wyniki badań PISA zwróciły uwagę na problem zróżnicowanego rozkładu osiągnięć polskich uczniów. Najgorsze wyniki uzyskali w większej skali niż

13 Dotychczas przeprowadzono cztery cykle badań z akcentem na wybraną dziedzinę: w $2000 \mathrm{r}$. — rozumienie tekstu, matematyka i nauka, w 2003 r. - akcentowano umiejętności matematyczne i dodano testy na umiejętność rozwiązywania problemów, w 2006 r. akcentowano umiejętności rozumowania naukowego. 
Wyniki nauczania polskich gimnazjalistów według badania PISA

\begin{tabular}{|l|c|c|c|}
\hline \multicolumn{1}{|c|}{ Wyniki badań PISA } & 2000 & 2003 & 2006 \\
\hline Przeciętne wskaźniki & & & 508 \\
• rozumienie tekstu & 479 & 497 & 495 \\
- matematyka & 470 & 490 & 498 \\
- nauka & 483 & 498 & - \\
- rozwiązywanie problemów & - & 487 & \\
\hline Zróżnicowanie wyników - procent na po- & & & \\
ziomach skrajnych* & $21,4 \%-, 10,6 \%+$ & $15,0 \%-, 13,8 \%+$ & $10 \%-, 11,6 \%+$ \\
- rozumienie tekstu & $26 \%-$ & $22,0 \%-, 10,1 \%+$ & $21 \%-, 10,6 \%+$ \\
- matematyka & $25 \%-$ & $17,6 \%-, 16,4 \%+$ & $19 \%-, 6,8 \%+$ \\
- nauka & - & $18 \%-, 12 \%+$ & - \\
- rozwiązywanie problemów & & \\
\hline
\end{tabular}

*Wyniki układane są na pięciu poziomach: od najniższego do najwyższego; procentowe wielkości oznaczają udział polskich uczniów w osiąganych wynikach na poziomie pierwszym (najgorszym) i piątym (najlepszym).

Źródło: OECD 2001; OECD 2007; Federowicz 2007.

przeciętnie, a rzadziej - najlepsze (w matematyce najgorsze wyniki w 2006 r. otrzymywało około $20 \%$ badanych 15 -latków, a najlepsze $10 \%$ ). Gorsze wyniki były istotnie zależne od statusu społeczno-ekonomicznego rodziców i rodzajów szkół, do jakich uczęszczali, co było pochodną statusu rodziców.

Problem różnic $\mathrm{w}$ osiągnięciach edukacyjnych stał się przedmiotem dalszych analiz, które zwróciły uwagę także na ogólniejsze zależności, a przede wszystkim na związek między nierównościami wśród rodziców w danym kraju a gorszymi osiągnięciami edukacyjnymi (Brook 2009). Badania wskazały także na istotną zależność osiągnięć szkolnych od poziomu dobrobytu (mierzonego wskaźnikiem PKB per capita) oraz od poziomu wydatków edukacyjnych na ucznia (OECD 2003; OECD 2007). Polska - z niskim PKB na osobę oraz niskimi wydatkami edukacyjnymi na ucznia - okazała się krajem edukacyjnie efektywnym. Wskaźniki osiągnięć polskich uczniów sytuowały się lekko powyżej krzywej ekonomicznego dobrobytu i wydatków edukacyjnych. Czyja to zasługa: systemu edukacyjnego, szkoły i nauczycieli czy rodziców? $\mathrm{Na}$ to pytanie nie ma jednoznacznej odpowiedzi.

Istnieje wiele opinii o tym, że wyniki edukacyjne młodzieży w Polsce w istotnym stopniu determinuje szkoła, uczestnicząca $\mathrm{w}$ procesie zmian transformacyjnych oraz zmian wywołanych akcesją do UE. Współczesną polską szkołę charakteryzują dwie cechy istotnie ją różniące od szkół wcześniejszych. Po pierwsze - nastawienie na wyniki nauczania, do czego przyczyniła się reforma edukacji i zewnętrzny system ocen (także wyniki badań PISA), dotyczący czysto kształceniowej funkcji szkoły. Funkcja ta pojmowana jest tak, że szkoła powinna przede wszystkim osiągać dobre wyniki nauczania, które są przedmiotem także wewnętrznej rywalizacji. Po drugie - odmiennością jest lokalne usytuowanie 
szkoły, co oznacza większe niż poprzednio oddziaływanie społecznego środowiska rodziców i samorządu terytorialnego (wynik reformy decentralizacyjnej). Te dwie tendencje dają w efekcie nowy typ instytucji szkolnej, znacznie mniej społecznej, a bardziej profesjonalno-klienckiej. Funkcje społeczno-wychowawcze szkoły są realizowane marginesowo, co powoduje że grupy młodzieży podatne na ubóstwo i wykluczenie społeczne nie znajdą w szkole wystarczających warunków do rekompensowania rozwojowych deficytów wyniesionych z domu i ze środowiska społecznego.

Polska młodzież nie lubi szkoły. Wyniki badań HBSC (WHO 2008b) wskazują, że tylko 13-14\% 15-latków lubi swoją szkołę, co jest wskaźnikiem znacznie poniżej przeciętnej dla krajów europejskich. W grupie krajów, których młodzież nie przepada za instytucją szkoły, jest wiele krajów postkomunistycznych. Może to sugerować, że w szkole utrzymuje się „duch” poprzedniej epoki, w której szkoła była znacznie bardziej rygorystyczna, a nawet bardziej represyjna niż obecnie.

Badania jakościowe, jakie w ramach projektu „Polska bieda III” przeprowadzono w wybranych polskich szkołach (Tarkowska 2007), sygnalizują występowanie zjawiska obojętności, a nawet niechęci do sytuacji zagrożeń rozwoju edukacyjnego na tle socjalnym. Badane szkoły w niskim stopniu pełniły oczekiwane funkcje prewencyjne w zwalczaniu ubóstwa i wykluczenia społecznego. Można by nawet postawić nieco przesadzoną tezę, że stygmatyzowały biednie dzieci i utrudniały pokonywanie deficytów i deprywacji. Preferencje polityki szkolnej koncentrowały się bowiem na dość jednostronnie pojmowanej funkcji kształceniowej; realizacji programów nauczania i akcentowaniu umiejętności rozwiązywania testów. W obecnych szkołach, jak wynika z sygnałów badawczych, za mało jest „przestrzeni” i warunków, także umiejętności, do rozwijania zainteresowań uczniów, motywowania do kreatywności, samodzielnego myślenia, a także sprawowania przez nauczycieli funkcji wychowawczych wobec uczniów. Wzrosły wprawdzie wymagania kwalifikacyjne wobec nauczycieli (muszą mieć wyższe wykształcenie), ale efekty wzrostu wykształcenia nie przekładają się jeszcze na wzrost kompetencji społeczno-wychowawczych. Ponadto wprowadzenie instytucji pedagoga szkolnego zwalnia innych nauczycieli od zajmowania się sprawami wykraczającymi poza program nauczania danego przedmiotu.

Ocena systemu edukacyjnego i polskiej szkoły jest raczej niska. Podstawowa opinia jest taka, że nie prowadzi się w naszym kraju jasno zdefiniowanej polityki edukacyjnej nawiązującej do strategii europejskich, w których edukacja jest podstawowym filarem rozwoju gospodarki opartej na wiedzy, a jednocześnie nie realizuje się tych elementów strategii inkluzji, które dotyczą postulatu równych szans dostępu do jakościowo dobrego sytemu szkolnego. W rezultacie Polska zdecydowanie należy do tych krajów, które nie nastawiają się ani na zwalczanie ubóstwa edukacyjnego, ani na formowanie elit (jest tak także w kilku innych krajach europejskich). 
Istotną, wręcz rewolucyjną, zmianą polskiego systemu edukacyjnego stało się upowszechnienie edukacji na poziomie wyższym. Jeśli w $1995 \mathrm{r}$. 38\% maturzystów szło na studia, to w końcu następnej dekady już 78\%, a bez mała $50 \%$ odpowiedniego rocznika kończyło je (w terminie) ${ }^{14}$. Tej skokowej zmianie ilościowej nie towarzyszyły odpowiednie nakłady na wzrost zasobów kadrowych oraz infrastrukturalnych wyższych uczelni, co odbiło się negatywnie na jakości kształcenia. Ofiarami tego niskiego poziomu programów i kształcenia stali się absolwenci licznych nowych, na ogół niepublicznych szkół wyższych ${ }^{15}$, usytuowanych w mniejszych miastach, którzy zasadniczo zasilili potencjał emigracji z Polski w pierwszej dekadzie XXI wieku. Niski poziom wielu szkół wyższych i wypuszczanie słabo przygotowanych absolwentów, którzy konfrontują się z wymagającym kwalifikacji rynkiem pracy (tak w kraju, jak i za granica) i mają wyższe aspiracje dochodowe, przyczynia się do podejmowania pracy poniżej kwalifikacji, często „byle jakiej”. Zjawisko to, zwane marnotrawstwem mózgów (brain waste) w odróżnieniu od drenażu mózgów (brain drain), można dostrzec w głównej mierze w najnowszej fali polskiej emigracji do krajów Europy Zachodniej (Bruecker 2009).

\section{PRACA MŁODZIEŻY}

Podejmując problem pracy dla młodzieży, należy rozróżnić dwa odrębne $\mathrm{w}$ istocie zagadnienia. Jedno dotyczy tych, którzy zakończyli edukację wcześniej niż po ukończeniu 24-go roku życia, ponieważ nie podjęli studiów. Skończyli jakąśs szkołę, albo o profilu zawodowym, dającą konkretne kwalifikacje, albo o profilu ogólnokształcącym — bez umiejętności zawodowych. Znalezienie pracy w tym drugim przypadku to trudne zadanie. Brak konkretnych umiejętności i doświadczenia zawodowego zmniejsza szanse na dobre zatrudnienie.

Problem drugiego rodzaju to praca dla młodzieży uczącej się lub studiującej, podejmującej pracę obok zajęć edukacyjnych. To częste zjawisko w wielu krajach. Praca ma wówczas znaczenie jako sposób zdobycia środków na utrzymanie w trakcie studiów czy na dodatkowe potrzeby młodych osób, a bywa i tak, że jest wcześniejszym startem do kariery zawodowej w zdobywanym zawodzie.

Zagrożenia związane $z$ przejściem $z$ systemu szkolnego na rynek pracy mają charakter zarówno uniwersalny, jak i specyficzny dla danej epoki. Młodzi ludzie $z$ zasady wchodzą do nowego świata $z$ dużymi oczekiwaniami, a pracodawcy podejmują ryzyko włączenia do zespołu pracowniczego kogoś o całkowicie nieznanych zachowaniach w pracy. Współcześnie zagrożenia te są większe. Rynek

14 Za tą średnią kryje się bardzo duże zróżnicowanie w przekroju płci. Młode kobiety kończą studia w terminie znacznie częściej niż młodzi mężczyźni (ponad 60\% i nieco poniżej 40\%) (OECD 2009b, s. 62).

15 Stosunkowo niedawno rozpoczął się pewien ruch medialny przeciwko niskiej jakości szkół wyższych („szkoły tego i owego”), rozwijany w debacie „Gazety Wyborczej” w 2009 roku. 
pracy jest bowiem bardziej dynamiczny i trudniejszy, a wymagania pracodawców większe - oczekują oni konkretnych umiejętności oraz doświadczenia i coraz rzadziej są skłonni kształcić młodych ludzi we własnym zakresie. W tej sytuacji ogromną rolę w wejściu na rynek pracy odgrywają: dobrej jakości i dostosowana do potrzeb edukacja, dostosowany system praktyk i staży oraz podejmowanie indywidualnych strategii zatrudnieniowych, zorientowanych bardziej na odpowiednią pracę niż uzyskiwanie dodatkowych dochodów.

Zagrożenia przyszłości młodzieży w sferze pracy polegają na:

— występowaniu zjawiska bierności: „ani w szkole, ani w pracy”;

- poszukiwaniu i podejmowaniu pracy bez przygotowania zawodowego;

- wykonywaniu w trakcie nauki pracy typu junk jobs, ograniczającej czas poświęcany na studiowanie;

- wykonywaniu pracy niskopłatnej przez długi okres;

- pozostawaniu w sytuacji długookresowego bezrobocia;

- podejmowaniu pracy zarobkowej za granicą poniżej kwalifikacji i przez długi okres;

- podejmowaniu pracy w trudnych warunkach: praca fizyczna ponad siły, nieprzestrzeganie regulacji dotyczących bezpieczeństwa pracy młodych ludzi, eksploatacja, mobbing i molestowanie seksualne w miejscu pracy.

Największe zagrożenie przyszłości młodzieży to bierność - niepodejmowanie pracy i nieuczestniczenie w systemie edukacji. Wskaźnik NEET (not in education, employment or training), wprowadzony do statystyki europejskiej stosunkowo niedawno (European Commission 2009), wzorem angielskiego podejścia zastosowanego w programie Transforming Youth Work (2000), ukazuje skalę zagrożenia społecznym wykluczeniem w okresie dorastania. Rozpoznane statystycznie przyczyny takiego stanu są zwykle następujące: trudności ze znalezieniem pracy, ucieczka w szarą strefę zarobkowania i życia, choroba i niepełnosprawność oraz sytuacja rodzinna (opieka nad dzieckiem sprawowana przez młode matki).

W krajach europejskich przeciętnie aż jedna trzecia młodych ludzi nie uczy się i nie pracuje. Głównym powodem są trudności ze znalezieniem pracy, tym bardziej że na rynek pracy w starych krajach europejskich wchodzi się wcześniej niż w nowych. W Polsce wskaźnik NEET jest znacznie niższy - wynosi $13 \%$. Młodzież długo pozostaje w systemie edukacji, ale ci, co się nie kształcą, mają większe trudności $z$ wejściem i pozostaniem na rynku pracy (wskaźnik bezrobocia polskiej młodzieży należy do najwyższych w UE). Praca dla młodzieży z niskimi kwalifikacjami najczęściej jest bardzo niskiej jakości; niskopłatna, krótkookresowa, bez ubezpieczenia, wykonywana w trudnych warunkach, fizyczna. Pewna grupa nieuczącej się młodzieży pracuje tylko okazjonalnie lub w ogóle nie podejmuje stałego zatrudnienia. Wchodzi w szarą strefę nie tylko zatrudnienia, ale szerzej - życia; zbliża się do środowisk utrzymujących się $z$ drobnych przestępstw; nielegalnego handlu i usług, kradzieży i rozbojów. Jak sygnalizują polskie badania, to brak stabilnej pracy w młodym wieku staje się 
Obszary potencjalnych zagrożeń rozwoju młodzieży w sferze pracy

\begin{tabular}{|c|c|}
\hline Obszary zagrożeń & Wskaźniki i dane \\
\hline $\begin{array}{l}\text { Bierność młodzieży: „ani w szkole, ani } \\
\text { w pracy” }\end{array}$ & $\begin{array}{l}\text { Wskaźnik NEET - neither in education nor in employment. } \\
\text { W krajach UE w sytuacji NEET przeciętnie znajduje się } \\
\text { znacznie więcej młodzieży w porównaniu z Polską. }\end{array}$ \\
\hline Trudne przejście ze szkoły do pracy & $\begin{array}{l}\text { Wskaźnik uczestnictwa w praktykach zawodowych i sta- } \\
\text { żach; trudno realizowane wymaganie. }\end{array}$ \\
\hline Pracujący w wieku młodzieżowym & $\begin{array}{l}\text { Wskaźnik pracujących (lub zatrudnionych) w wieku 15- } \\
-19 \text { oraz } 15-24 \text { lat. W krajach UE przeciętnie 50\% osób } \\
\text { w wieku } 20 \text { lat jest aktywnych zawodowo. }\end{array}$ \\
\hline Pracujący i studiujący & $\begin{array}{l}\text { Stosunek pracujących studentów do wszystkich studiują- } \\
\text { cych na poziomie wyższym; około } 31 \% \text { polskich studen- } \\
\text { tów pracuje. }\end{array}$ \\
\hline Charakter pracy dla młodzieży & $\begin{array}{l}\text { Oferty pracy „elastycznej”: okresowej ( } 65 \% \text { pracującej } \\
\text { młodzieży w UE ma kontrakt czasowy), w niepełnym wy- } \\
\text { miarze, poniżej kwalifikacji (junk jobs). }\end{array}$ \\
\hline Praca poniżej kwalifikacji & $\begin{array}{l}\text { Udział osób z wyższymi kwalifikacjami na stanowiskach } \\
\text { pracy nie wymagających wyższego wykształcenia; wysoki } \\
\text { wskaźnik w odniesieniu do pracy Polaków za granicą. }\end{array}$ \\
\hline Praca zarobkowa za granicą & $\begin{array}{l}\text { Pracujący za granicą do pracujących w kraju w danej gru- } \\
\text { pie wieku. Nowe kraje członkowskie UE są ciągle za- } \\
\text { pleczem służącym uzupełnianiu podaży pracy w krajach } \\
\text { przyjmujących starej Unii. }\end{array}$ \\
\hline Niskie opłacanie pracy młodych ludzi & $\begin{array}{l}\text { Relacja płacy młodzieży do płacy osób dorosłych (powy- } \\
\text { żej } 24 \text { lat) lub płacy przeciętnej. Istotnie niższe płace dla } \\
\text { młodzieży oferują pracodawcy w UE. }\end{array}$ \\
\hline $\begin{array}{l}\text { Ograniczone kształcenie młodych pra- } \\
\text { cowników przez pracodawców }\end{array}$ & $\begin{array}{l}\text { Udział dłuższych szkoleń dla młodych pracowników fi- } \\
\text { nansowanych przez pracodawców; tendencja - raczej ak- } \\
\text { ceptowanie szkoleń podejmowanych i opłacanych indywi- } \\
\text { dualnie w czasie wolnym od pracy. }\end{array}$ \\
\hline Trudne warunki pracy młodych ludzi & $\begin{array}{l}\text { Nieprzestrzeganie regulacji dotyczących bhp, wymaganie } \\
\text { wysokiego stopnia gotowości do pracy ponadwymiaro- } \\
\text { wej, nieubezpieczanie młodych pracowników, specyficzne } \\
\text { traktowanie młodych kobiet. }\end{array}$ \\
\hline Bezrobocie młodzieży & $\begin{array}{l}\text { Stopa bezrobocia - w krajach UE wynosi 15,4\% (2007 r.) } \\
\text { w odniesieniu do aktywnych zawodowo w tym wieku. } \\
\text { Bezrobocie polskiej młodzieży najwyższe w Europie. } \\
\text { Długotrwałe bezrobocie. }\end{array}$ \\
\hline
\end{tabular}

Źródło: zestawienie własne na podstawie European Commission 2009 i OECD 2009a.

bardziej prawdopodobną przyczyną wejścia na drogę przestępczości niż bieda rodziców (Kiersztyn 2008).

Zagrożenie przyszłości młodych ludzi wynika także z oferty systemu szkolnego. Gdy jest ona - już na poziomie średnim — słabo zróżnicowana i ograniczona pod względem kształcenia umiejętności przydatnych w życiu i przygo- 
towania zawodowego, to potencjalnie najbardziej zagrożone grupy młodzieży: $z$ trudnościami w edukacji ogólnej oraz pochodzące ze środowisk biedniejszych i o niższych aspiracjach edukacyjnych, nie znajdą sobie miejsca pozwalającego na satysfakcjonujące budowanie przyszłości zawodowej. Szkoły zawodowe na poziomie średnim są potrzebne nie tylko ze względu na rynek pracy, są potrzebne także młodzieży, która może zbudować swą przyszłość na przygotowaniu do pożytecznego zawodu, nie wymagającego ogólniejszego wykształcenia i studiów.

Oferta szkolnictwa zawodowego na poziomie średnim w starych krajach Europy jest bogata i urozmaicona. Bez mała $60 \%$ młodzieży uczestniczy w różnych formach przygotowania zawodowego: podejmując naukę zawodu w szkołach zawodowych, u pracodawcy oraz w systemach dualnych (szkoła i zakład pracy jednocześnie). Nowe kraje członkowskie natomiast masowo odeszły od kształcenia zawodowego, zwłaszcza Polska i Węgry. Udział w systemach szkolnych uczniów przygotowujących się do zawodu jest obecnie w Polsce dwukrotnie, a na Węgrzech trzykrotnie niższy w porównaniu z przeciętnym wskaźnikiem dla starej Unii. Wyjątkiem są Czechy, które w okresie transformacji zastosowały całkowicie odmienną politykę edukacyjną, ich wskaźnik w tej dziedzinie kształtuje się na poziomie 68\% (Badescu 2008).

Niedocenianie kształcenia umiejętności oraz edukacji zawodowej jest poważnym mankamentem polskiej polityki edukacyjnej. Dotyczy to także szkolnictwa wyższego, w którym walka o profesjonalnie przygotowane i realizowane praktyki oraz staże ma miejsce także obecnie ${ }^{16}$, gdy wskaźnik relacji kadr do studentów już jest korzystniejszy.

Trudny start młodzieży na rynku pracy oraz relatywnie wysokie wskaźniki ubóstwa tej kategorii wynikają także ze specyficznej polityki wynagradzania młodych ludzi. Im młodsze osoby i mniej zawodowo przygotowane wchodzą na rynek pracy, tym bardziej „głodowe” oferuje się im płace. Nawet kategoria płacy minimalnej dla młodych pracowników jest w wielu krajach ustalana na poziomie niższym niż dla pozostałych grup. Młodzi mogą bowiem liczyć na pomoc rodziców, a pracodawcy są w ten sposób zachęcani do zatrudniania osób niedoświadczonych. Gdy jednak na rynek pracy wchodzą osoby nie tylko bez domowego zaplecza, ale ponadto obciążone własnymi problemami materialnymi (bez mieszkania, a może już z własną rodziną), to praca na otwartym i legalnym rynku nie jest dla nich wystarczającym środkiem budowania stabilnej przyszłości. Jednak młodzi ludzie zaprawieni w pokonywaniu trudności rynku pracy łatwiej sobie radzą z przechodzeniem różnych faz rozwoju zawodowego, łączenia pracy i szkoleń oraz przeczekiwania braku pracy w ramach programów aktywnej polityki rynku pracy. Europejskie badania znane

\footnotetext{
16 Na przykład niektóre uczelnie nie wliczają obowiązkowych praktyk studenckich do programu nauczania.
} 
jako SPREW ${ }^{17}$ sygnalizują, że obecne młode pokolenie pracowników, chociaż bardziej narażone na niskie dochody i gorszą pracę, lepiej niż pokolenie starsze wykorzystuje możliwości informacyjno-edukacyjne oraz instrumenty ochrony socjalnej bezrobotnych na dobrze pod tym względem oprzyrządowanym rynku pracy w krajach starej Unii. W nowych krajach członkowskich UE młodzi ludzie muszą bardziej liczyć na swoje i rodziców siły. Niejednokrotnie poszukują więc pracy za granica, obecnie głównie tam, gdzie mogą ją wykonywać legalnie.

Zdobywanie doświadczenia zawodowego stało się wśród młodych ludzi jednym ze sposobów „gładszego” wchodzenia na rynek pracy. Coraz częściej więc uczą się i pracują jednocześnie. W szkołach średnich zdecydowanie przeszkadza to $\mathrm{w}$ procesie edukacji, jeśli pracuje się także w ciągu roku szkolnego, a nie tylko w czasie wakacji, to niejednokrotnie przyczynia się do opuszczenia szkoły.

Łączenie pracy i nauki w okresie studiów zaczyna się upowszechniać i mniej przeszkadza, jak się wydaje, w procesie edukacji, jeśli to praca, a nie edukacja jest elementem dodatkowym. Pogodzić pracę i edukację pozwalają tzw. studia zaoczne. W Polsce rozwinęły się na skalę masową.

Studenci podejmujący pracę $\mathrm{w}$ trakcie studiów często czynią to także $z$ powodów zarobkowych, a nie tylko ze względu na możliwość zdobycia doświadczenia zawodowego. Gdy chodzi głównie o dochód, to młodzi ludzie orientują się na prace bardziej dostosowane do czasu wolnego od zajęć, sezonowe i proste, na ogół takie, które można zaliczyć do kategorii śmieciowych (junk jobs). Pozwalają one na skromny zarobek, bardziej jako rodzaj kieszonkowego niż podstawa utrzymania. Wykonywanie takiej pracy staje się zagrożeniem rozwoju, gdy trwa zbyt długo i w końcu utrwala się. Nie dość, że zarobek jest niski, a praca monotonna i prosta, to koszt alternatywny - bardzo wysoki. W tym czasie można by bowiem niezwykle efektywnie ugruntować i podnieść kwalifikacje, inwestując w lepszą przyszłość. Zagrożenie negatywnymi skutkami zbyt długiego okresu wykonywania przez młodych ludzi pracy śmieciowej dotyczy zwłaszcza imigrantów zarobkowych, którzy zdobywszy jakieś zajęcie, wpadają $\mathrm{w}$ pułapkę wykonywania go przez lata $\mathrm{w}$ obawie przed ryzykiem zmiany $\mathrm{w}$ niepewnych warunkach.

Wysokie bezrobocie wśród młodzieży jest uwarunkowane przede wszystkim słabym rozwojem gospodarczym oraz fluktuacjami koniunktury, co bardziej dotyka wchodzących na rynek pracy niż już pracujących, których bronią związki zawodowe. W okresie transformacji gospodarczej w krajach postkomunistycznych działał czynnik dodatkowy, mianowicie dynamiczna restrukturyzacja gospodarcza, która dramatycznie zmieniała rynek pracy. Zwłaszcza w Polsce, gdzie system edukacji nie łagodził trudności z wejściem na rynek pracy, młodzi ludzie doświadczyli i ciągle doświadczają na starcie sytuacji braku dla nich

17 Projekt SPREW był realizowany w ramach szóstego programu ramowego UE (Citizens and Governance Programme) w okresie 2006-2008 i uwzględniał analizy z sześciu krajów: Belgii, Francji, Niemiec, Węgier, Włoch i Portugalii (http://www.ftu-namur.org/sprew). 
pracy. Stopa bezrobocia młodych osób w wieku 15-24 lata w Polsce nadal należy do najwyższych $w$ krajach UE, co wynika $z$ generalnie wysokiego bezrobocia w Polsce. Faktem jest bowiem, że stopa bezrobocia młodych jest w każdym kraju wyższa niż przeciętnie; dwukrotnie, a w niektórych krajach nawet trzykrotnie (European Commission 2009). W Polsce wysoki wskaźnik bezrobocia młodzieży utrzymuje się nadal, mimo że znaczna część młodej populacji pracuje za granicą. Jednocześnie gospodarka, która zaczęła zgłaszać większy popyt na pracę, spotyka się z niedostosowaniem kwalifikacyjnym młodych ludzi. Pilnym wyzwaniem staje się więc zmiana sytemu edukacyjnego, uwzględniająca także kształcenie w okresie zatrudnienia.

Tabela 3

Stopa ubóstwa młodzieży w wieku 16-24 lata w porównaniu ze stopą ubóstwa dorosłych w wieku 25-49 w krajach europejskich

\begin{tabular}{|l|c|c|}
\hline \multicolumn{1}{|c|}{ Grupy krajów } & $\begin{array}{c}\text { Stopa ubóstwa młodzieży } \\
\text { w wieku 16-24 (w \%) }\end{array}$ & $\begin{array}{c}\text { Stopa ubóstwa dorosłych } \\
\text { w wieku 24-49 (w \%) }\end{array}$ \\
\hline $\begin{array}{l}\text { Dania, Norwegia } \\
\text { Szwecja, Bułgaria, Rumunia } \\
\text { Finlandia, Francja, Niemcy Włochy, } \\
\quad \text { Pols k a, Grecja }\end{array}$ & $\begin{array}{c}\text { Powyżej 30 } \\
\text { niewiele powyżej 10 } \\
12-27,5\end{array}$ \\
$\begin{array}{l}\text { Belgia, Portugalia, Estonia, Łotwa, Irlan- } \\
\text { dia, Węgry, Holandia, Wielka Brytania, }\end{array}$ & $21-25$ & $13-20$ \\
$\quad$ Hiszpania & $16-20$ & $15-20$ \\
Czechy, Austria, Słowacja, Słowenia, Litwa & $10-15$ & $10-12$ \\
\hline
\end{tabular}

Uwaga: stopa ubóstwa mierzona jest jako udział młodych osób żyjących poniżej $60 \%$ mediany ekwiwalentnych dochodów do dyspozycji w całkowitej liczbie populacji.

Źródło: Eurostat 2010 na podstawie badań EU-SILC z 2007 r.

Trudny start na rynku pracy to najczęstsze źródło ubóstwa młodzieży, chociaż zaraz po tym istotną rolę odgrywa pozycja ekonomiczna rodziców. Jak dowodzą wyniki europejskich badań EU-SILC, rozmiary ubóstwa wśród młodzieży w większości krajów UE są wyższe niż wśród osób dorosłych (zob. tabela 3). Około $20 \%$ pracującej młodzieży w wieku 18-24 lata zarabia mniej niż 50\% przeciętnego dochodu w danym kraju (European Commission 2009). W Polsce wskaźnik ubóstwa młodzieży należy do drugiej grupy najwyższych spośród krajów europejskich. Różnica w porównaniu ze wskaźnikiem dla dorosłych nie jest duża. W kilku krajach europejskich różnica między wskaźnikami ubóstwa dla młodych i dorosłych (do pięćdziesiątego roku życia) jest znaczna na niekorzyść młodych, na przykład w Danii, Szwecji oraz Norwegii ${ }^{18}$ (Eurostat 2009).

\footnotetext{
18 Poszukiwanie wyjaśnienia tej różnicy w Szwecji i w Danii, dwóch krajach Europy o najlepszych zabezpieczeniach socjalnych, wskazuje nie tyle na występowanie jakichś dyskryminacyjnych mechanizmów, ile na zwyczaj bardzo szybkiego usamodzielniania się młodych ludzi w Skandynawii w porównaniu z innymi krajami Europy.
} 
Dostęp do przyjaznego dla rynku pracy systemu edukacji jest najbardziej efektywnym sposobem zwalczania ubóstwa młodzieży. Dostęp ten jest istotnie ułatwiany przez system stypendialny. Gdy system ten jest ograniczony, to ciężar utrzymania i kształcenia dzieci spada na rodziców. Tylko zamożniejsi rodzice są w stanie temu należycie sprostać. Ograniczenia stypendialne przyczyniają się więc do utrzymania nierówności społecznych i ich pogłębienia.

W krajach UE bardziej popularne niż stypendia są specjalne pożyczki i kredyty. W Polsce system stypendialny jest wprawdzie rozbudowany; istnieje wiele różnych rodzajów stypendiów (naukowe, socjalne, sportowe, kulturalne...) i wielu grantodawców (UE, agendy rządowe, samorządy terytorialne, organizacje pozarządowe, organizacje religijne, media...), ale stypendia są bardzo niskie (od kilkudziesięciu do 200-300 PLN miesięcznie) i stanowią raczej rodzaj kieszonkowego niż kwotę pokrywającą jakieś poważniejsze koszty utrzymania studenta, na przykład koszty mieszkaniowe (Akademia Rozwoju Filantropii 2006). W sumie - stypendia w niewielkim stopniu zwiększają dostęp do edukacji osób mniej zamożnych i pochodzących z małych miast oraz wsi, czyli tych, którzy mają wyższe koszty utrzymania na studiach ze względu na oddalenie od domu rodzinnego.

Trudności młodych ludzi z wejściem na rynek pracy oraz zagrożenie ubóstwem sprzyja długiemu okresowi pozostawania w zależności od rodziców, obecnie dłuższemu niż jeszcze dwadzieścia lat temu (Eurobarometr 2007). Odzwierciedla to wskaźnik wieku, w którym młodzi ludzie opuszczają dom rodzinny. W krajach UE przeciętny wiek opuszczania domu rodzinnego wynosi 25 lat. Wcześniej czynią to kobiety niż mężczyźni. Jako przyczynę opóźnień podają trudności $z$ samodzielnym utrzymaniem się (44\%) oraz brak odpowiednich zasobów mieszkaniowych w swoim kraju (28\%). Na trzecim miejscu wskazują wygodę mieszkania z rodzicami (16\%). Różnice między krajami są duże. Późne wyprowadzanie się od rodziców jest charakterystyczne dla młodych ludzi z nowych krajów członkowskich (rekordowo wysokie w Bułgarii, na Słowacji i w Słowenii), ale występuje także w krajach starej Unii, na przykład we Włoszech czy w Grecji, gdzie obok czynników ekonomicznych równie istotną rolę odgrywają czynniki kulturowe.

W Polsce młodzi ludzie opuszczają dom rodziców przeciętnie w wieku trzydziestu lat. Głównym powodem tak późnego wychodzenia $z$ domu rodzinnego są trudności ekonomiczne wynikające $z$ niskich i niestabilnych dochodów oraz brak mieszkań dostępnych dla budżetu młodego człowieka. Ograniczone są zwłaszcza możliwości sfinansowania własnego mieszkania. Dostęp do kredytów mieszkaniowych jest zależny od rodzaju umowy o pracę, a wśród młodych dominują formy niestabilne: kontrakty okresowe, umowy zadaniowe itp. Najszybciej i najłatwiej opuszcza się dom rodzinny przez emigrację. Ciągle wydaje się to młodzieży najpewniejszym sposobem na zdobycie samodzielności i na zmniejszenie zagrożenia ubóstwem. 


\section{WNIOSKI}

Wielowymiarowe spojrzenie na sytuację młodzieży w Polsce na tle porównawczym potwierdza tezę o wysokiej podatności młodych ludzi na zagrożenia ich zrównoważonego rozwoju. Charakter tych zagrożeń jest zarówno uniwersalny, typowy dla okresu dorastania, specyficzny dla krajów transformacji, jak i specyficzny dla Polski - kraju o odmiennej strukturze społeczno-gospodarczej, dynamiczniejszym rozwoju instytucji gospodarki rynkowej oraz nieco innych wartościach i aspiracjach społecznych w porównaniu zarówno z krajami Europy Środkowej i Wschodniej, jak i z krajami Europy Zachodniej. Zagrożenia rozwoju młodzieży dotyczą każdej ze sfer: zdrowia somatycznego i psychicznego, dostępu do dobrej i efektywnej z punktu widzenia rynku pracy edukacji, rozwoju intelektualnego i społecznego oraz relacji z rodziną i otoczeniem. Główne problemy, większe w porównaniu z krajami UE, wynikają z trudności zewnętrznych, czyli trudno dostępnych i niedostosowanych instytucji ochrony zdrowia i dobrej edukacji, braków infrastruktury dla młodzieży i słabej infrastruktury życia publicznego, narażającej młodych ludzi na wypadki, urazy i stresy. Dramatycznie trudne jest przejście młodych ludzi ze szkoły na rynek pracy. Niepokojące są wskaźniki mówiące o słabej partycypacji społecznej młodzieży, nieangażowaniu się w sprawy ogólniejsze i ucieczce $\mathrm{w}$ świat tworzony przez elektroniczne media. Przezwyciężanie tych zewnętrznych ograniczeń staje się udziałem tylko młodzieży pochodzącej z zamożniejszych domów. W rezultacie - to w okresie dzieciństwa oraz dorastania rodzą się nierówności społeczne, które później tylko się utrwalają i pogłębiają.

Pozytywna i specyficzna cecha rozwoju młodzieży w Polsce to jej (i rodziców) relatywnie wysokie aspiracje edukacyjne, które lepiej ulokowane w strukturze szkół pozwalających zdobywać dostosowane do potrzeb umiejętności i kwalifikacje - mogłyby dać znacznie korzystniejszy efekt na rynku pracy i w rozwoju społeczno-gospodarczym. Wymagałoby to wprowadzenia dość istotnych zmian w systemie szkolnictwa średniego i wyższego; przeorientowania go na efekty jakościowe i otwarcia na zmiany społeczne oraz pobudzania i wspierania inicjatywności i innowacyjności. Współczesna szkoła średnia i wyższa, jak pokazują badania oraz wnioski z debaty prowadzonej przez „Gazetę Wyborczą" w latach 2008-2009, jest mało innowacyjna, aspołeczna oraz nieefektywna z punktu widzenia rynku pracy. Być może zmniejszenie (na skutek zmian demograficznych) liczby kandydatów do placówek edukacyjnych wpłynie na zmianę dotychczasowych antyjakościowych tendencji. W wysokiej cenie będzie bowiem każdy kandydat. Szkoły będą musiały dokładać większych starań, aby pozyskiwać uczniów i studentów, a gdy będzie ich mniej, to i o odpowiednie zasoby nie będzie już tak bardzo trudno. W konsekwencji także absolwenci powinni być lepsi, bardziej dynamiczni, produktywni i społeczni. Od tego, jacy będą, zależeć będzie rozwój kraju. 
Komisja Europejska wychodzi już z inicjatywą w tej dziedzinie. Planuje włączyć do wspólnych strategii europejskich opartych na metodzie otwartej koordynacji strategię na rzecz młodzieży (Strategy for Youth - Investing and Empowering), mobilizując kraje członkowskie do inwestowania w edukację oraz rozwój społecznych i odpowiedzialnych zachowań młodych ludzi, którzy $\mathrm{w}$ dodatku będą musieli sprostać znacznie trudniejszym wyzwaniom przyszłości niż pokolenie ich rodziców.

\section{BIBLIOGRAFIA}

Akademia Rozwoju Filantropii, 2006, Rynek stypendiów w Polsce. Raport 2006, Instytut Obsidian, Warszawa.

Allmendinger Jutta, Leibfried Stephan, 2003, Education and the Welfare State. Germany's Poverty and Plenty and the Many Worlds of "Competence Distribution" in the EC and the OECD, „Journal of European Social Policy”, t. 13, s. 63-81.

Badescu Mircea, 2008, Improving the Scope of Indicators for Monitoring Developments in Vocational Education and Training in Europe, Joint Research Centre (JRC) Scientific and Technical Report, European Commission, Brussels.

Białek Ewa D., 2009, Zrównoważony rozwój dziecka w świetle nowych wyzwań, Wydawnictwo Impuls, Białystok.

Binkowska-Bury Monika, 2009, Zachowania zdrowotne młodzieży akademickiej, Wydawnictwo Uniwersytetu Rzeszowskiego, Rzeszów.

Bjarnason Thoroddur i in., 2004, Divorce, Cohort Characteristics, and Changes in Youth Suicide Rates: A Multinational, Time-Series Analysis. Paper presented at the annual meeting of the American Sociological Association (http://www.allacademic.com/meta/ p109884_index.html).

Brook Anne-Maria, 2008, Raising Education Achievement and Breaking the Cycle of Inequality in the United Kingdom, OECD Economics Department Working Papers nr 633, Paris.

Bruecker Herbert, 2009, Labour Mobility within the EU in the Context of Enlargement and the Functioning of the Transitional Arrangements, raport $\mathrm{z}$ wykonania projektu dla Komisji Europejskiej zrealizowanego w IAB, Norymberga.

CASP, 2007, Bezpieczeństwo dzieci. Prewencja urazów dzieci. Raport dla Polski 2007, Child Safety Action Plan, Kraków.

Carter Richard, 2005, Family Matters: A Study of Institutional Childcare in Central and Eastern Europe and The Former Soviet Union, Every Child, London.

Diagnoza, 2007, Diagnoza społeczna 2007, niezależne badanie warunków $i$ jakości życia w Polsce, Rada Monitoringu Społecznego, Warszawa.

ESPAD, 2007, Alcohol and Drug Use Among European 17-18 Year Old Students. Data of the "The European School Survey Project on Alcohol and Other Drugs", Swedish Council for Information on Alcohol and Other Drugs (CAN), The Pompidou Group at the Council of Europe and the authors: Bjoern Hibell, Barbro Andersson, Stockholm.

Eurobarometr, 2007, Young Europeans. Survey among young people aged between 15-30 in the European Union, European Commission and The Gallup Organization, Brussels.

European Commission, 2001, White Paper: A New Impetus for European Youth, $\operatorname{COM}(2001) 681$, Brussels. 
European Commission, 2004, New Indicators on Education and Training, Commission Staff Working Paper, SEC (2004) 1224 Brussels.

European Commission, 2005, Study on Access to Education and Training, Basic Skills and Early School Leavers, Lot 3: Early School Leavers, Ref. DG EAC 38/04, GHK, London.

European Commission, 2009, Youth - Investing and Empowering, Youth Report, Brussels.

European Commission, 2009, European Research on Youth. Supporting Young People To Participate Fully in Society, Eurostat (2009), Youth in Europe. Statistical portrait, Luxembourg.

Eurostat, 2009, Youth in Europe: A Statistical Portrait, Luxembourg.

Federowicz Michał (red.), 2007, Umiejętności polskich gimnazjalistów. Pomiar. Wyniki. Zadania testowe $z$ komentarzami, IFiS PAN, Warszawa.

Frindt Anna, 2005, Czy warto być dorostym? Społeczno-kulturowe uwarunkowania pojęcia dorosłości $w$ świadomości młodzieży wielkomiejskiej, Wydawnictwo Akademickie Żak, Warszawa.

Fundacja „Rodzić po ludzku”, 2009, Monitoring realizacji działań administracji samorządowej w zakresie opieki nad matką i dzieckiem, Warszawa.

Giermanowska Ewa, Racław-Markowska Mariola, 2007, Lisy usamodzielnianych wychowanków domów dziecka; w Elżbieta Tarkowska (red.), Ubóstwo i wykluczenie społeczne młodzieży, IPiSS, Warszawa.

Grzelak Szymon, 2009, Profilaktyka ryzykownych zachowań seksualnych młodzieży. Aktualny stan badań na świecie $i$ w Polsce, Rubikon, Kraków.

Imamura Mari i in., 2007, Factors Associated with Teenage Pregnancy in the European Union Countries: A Systematic Review, „European Journal of Public Health”, t. 17, nr 6, s. 630-636.

Kiersztyn Anna, 2008, Czy bieda czyni złodzieja? Związki między bezrobociem, ubóstwem a przestępczościa, Wydawnictwa Uniwersytetu Warszawskiego, Warszawa.

Klasen Stephen, 1998, Social Exclusion, Children, and Education: Conceptual and Measurement Issues, OECD (materiał konferencyjny).

Lwow Felicja, Dunajska Katarzyna, Milewicz Andrzej, 2007, Występowanie czynników ryzyka jadłowstrętu psychicznego i bulimii u 18-letnich dziewcząt, „Endokrynologia, Otyłość, Zaburzenia Przemiany Materii”, t. 3, nr 3.

Mazur Joanna, Woynarowska Barbara, 2004, Mierniki nierówności społecznych $w$ badaniach ankietowych młodzieży szkolnej, „Przegląd Epidemiologiczny”, nr 58, s. 377-390.

Menchini Leonardo, Marnie Sheila, Tiberti Luca 2009, Child Well-Being in Eastern Europe and Central Asia: A Multidimensional Approach, Innocenti Working Paper 20, UNICEF Innocenti Research Centre, Florence.

Mianowska Edyta, 2008, Strategie społecznego uczestnictwa młodzieży, Impuls, Kraków.

NIK, 2003, Informacja NIK o wynikach kontroli obowiązku szkolnego, sygn. KNO-41002/2002, Warszawa.

OECD, 2001, PISA 2000, Paris.

OECD, 2001 i 2006, Early Childhood Education and Care I and II, OECD reports, Paris.

OECD, 2003, Literacy Skills for the World of Tomorrow - Further results from PISA 2000, Paris.

OECD, 2004, Education at Glance, Paris.

OECD, 2007, PISA 2006: Science Competencies for Tomorrow's World, Paris.

OECD, 2009a, Jobs for Youth. Poland Case, Paris.

OECD, 2009b, Education at a Glance 2009. OECD Indicators, Paris. 
Parens Erik, Johnston Josephine, 2008, Mental Health in Children and Adolescents, w: Mary Crowley (red.), From Birth to Death and Bench to Clinic: The Hastings Center Bioethics Briefing Book for Journalists, Policymakers, and Campaigns, The Hastings Center, New York.

Robson Karen, Berthoud Richard, 2003, Teenage Motherhood in Europe: A Multi-Country Analysis of Socioeconomic Outcomes, „European Sociological Review”, t. 19, s. 451-466.

Rożnowski Bohdan, 2009, Przechodzenie młodzieży z systemu edukacji na rynek pracy w Polsce, Wydawnictwo KUL, Lublin.

Ryan-Krause Patricia i in., 2009, Developmental Status of Children of Teen Mothers: Contrasting Objective Assessment with Maternal Reports, „Pediatric Health Care”, t. 23, nr 5, s. 303-309.

Szafraniec Krystyna, 2009, Jacy sa młodzi Polacy?, w: W poszukiwaniu portretu Polaków, Instytut Badań nad Gospodarką Rynkową, Gdańsk.

Syrek Ewa, 2008, Zdrowie i wychowanie a jakość życia. Perspektywy i humanistyczne orientacje poznawcze, Wydawnictwo Uniwersytetu Śląskiego, Katowice.

Szymborski Janusz, Jakóbik Krzysztof (red.), 2008, Zdrowie dzieci i młodzieży w Polsce, Biuro Rzecznika Praw Obywatelskich-GUS, Warszawa.

Tarkowska Elżbieta (red.), 2007, Ubóstwo i wykluczenie społeczne młodzieży, IPiSS, Warszawa.

Tarkowska Elżbieta, 2009, Młodzież $i$ jej świat społeczny, w: Więzi społeczne $i$ przemiany gospodarcze. Polska i inne kraje gospodarcze, praca zbiorowa, IPiSS-Wydział Nauk Społecznych UW, Warszawa.

UNFPA, 2008, Putting Young People Into National Poverty Reduction Strategies: A Guide to Statistics on Young People in Poverty, New York.

UNICEF, 2009, Child Well-Being at a Crossroads: Evolving Challenges in Central and Eastern Europe and the Commonwealth of Independent States, „Innocenti Social Monitor”, The UNICEF Innocenti Research Centre, Florence.

Wajszczyk Bożena i in., 2008, Jakościowa ocena żywienia młodzieży w okresie pokwitania, „Problemy Higieny i Epidemiologii”, t. 89, nr 1.

Wąsowska K., 2007, „Wagary jako przejaw oporu wobec szkoły”, niepublikowana praca magisterska, obroniona w Instytucie Socjologii UW, Warszawa (za: Zahorska 2009).

WHO, 2004, Global Burden of Disease, World Health Organization, Geneva.

WHO, 2008a, World Report on Child Injury Prevention, Margie Peden i in. (red.), World Health Organization, Geneva.

WHO, 2008b, Health Behaviour in School-aged Children (HBSC), World Health Organization, Geneva.

Zahorska Marta, 2009, Równi, równiejsi i... najmniej równi, czyli o społecznych barierach $w$ dostępie do edukacji, „Polityka Społeczna”, nr 9: Polityka społeczna wobec dziecka.

ZNP, 2002 i 2007, Wyniki badań ankietowych na temat sytuacji placówek opiekuńczo-wychowawczych, Związek Nauczycielstwa Polskiego, Warszawa.

\section{THE SUSCEPTIBILITY OF THE YOUNG TO POVERTY AND SOCIAL EXCLUSION}

Sum mary

The author presents a multi-aspectual picture of the situation of young people in Poland in a comparative framework. This confirms the theory of the susceptibility of 
young people to the threats to the equilibrium of their development. These are both universal problems, universal for the period of entering adulthood, as well as specific ones connected with countries in transformation like Poland. This is observable in many spheres: somatic and psychological health, access to education of adequate quality and fitted to the job market, intellectual and social development and in relationships with the family and surrounding environment. In Poland the study showed that the main problem, to a greater extent than in countries of the EU were the result of limitations on access to healthcare institutions and education and lacks in the infrastructure of public life. The situation of young people entering the job market from school is dramatically bad. There are disturbing indications of their weak social participation, lack of involvement in general matters and escape into a world created by the electronic media. The ability to overcome these limitations is exhibited only by the young people from the wealthier households, which is decisive in the creation of social inequalities during their childhood and adolescence which later only become more permanent and deeper.

A specific positive characteristic of young people in Poland (and their parents) is their relatively high educational aspirations, which correctly applied - in the structure of schools allowing them to achieve skills and qualifications suitable for their needs can have positive effects on the job marketplace and socio-economic development. This however requires a reorientation of the system of middle and higher education to the production of quality, open to social change and awakening and supporting initiative and innovation. The European Commission has taken the initiative in this regard, proposing the Strategy for Youth — Investing and Empowering.

\section{Key words/słowa kluczowe}

Polish youth / polska młodzież; education / edukacja; the work marketplace / rynek pracy; exclusion / wykluczenie 